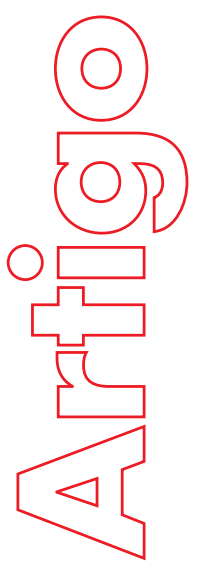

\title{
CONFLITOS SÓCIO AMBIENTAIS NA BACIA DO CORREGO SAMAMBAIA, DISTRITO FEDERAL
}

\author{
Nilton Goulart \\ Rafael Sanzio Araújo dos Anjos
}

p. $86: 124$

Como citar este artigo

Goulart. N . Rafael Sanzio Araújo Dos Anjos CONFLITOS SÓCIO AMBIENTAIS NA BACIA DO CÓRREGO SAMAMBAIA DISTRITO FEDERAL

Disponível em:

http://inseer.ibict.br/ciga/index.php/ciga/article/viewFile/288/207

Revista Eletrônica: Tempo - Técnica - Território, v.3, n.1 (2012), p.

86:124 ISSN: 2177-4366. DOI: https://doi.org/10.26512/ciga.v3i1.22234

Este obra está licenciado com uma Licença Crea tive Commons Atribuição-NãoComer cial 4.0 Inter nacional. 


\title{
CONFLITOS SÓCIO AMBIENTAIS NA BACIA DO CÓRREGO SAMAMBAIA, DISTRITO FEDERAL
}

\author{
NILTON GOULART \\ Mestrado em Geografia. \\ UnB - Universidade de Brasília \\ Bacharel em Engenharia Florestal pela Universidade de Brasília \\ Email: goulart.sousa@gmail.com
}

\begin{abstract}
RAFAEL SANZIO ARAÚJO DOS ANJOS
Geógrafo (UFBa.), Doutor em Informações Espaciais (POLIUSP-BR/IRD-FR.), PósDoutorado Cartografia Étnica (MRAC-BE). Prof. Associado do Depto. de Geografia da Universidade de Brasília (UnB) / Diretor do Centro de Cartografia Aplicada e Informação Geográfica da UnB e Coordenador do Projeto Geografia Afro-Brasileira: Educação \& Planejamento do Território.

Tel: 55(61)3107-7242 E-mail:cartografia@unb.br Site:www.unb.br/ih/ciga \& www.rafaelsanziodosanjos.com.br
\end{abstract}

Resumo: A questão da temática ambiental pode também ser vista sob a ótica do conflito, já que os recursos naturais são e serão objetos de disputas e interesses. Sob essa égide, as questões do meio ambiente podem ser classificadas segundo tipos diferentes de conflito, e decorrem da disputa ou desentendimento relacionados com o uso e/ou exploração dos recursos naturais, tendendo a aumentar com a escassez e competição pelo bem natural. No final do século 20 os conflitos relacionados ao meio ambiente começaram a ser estudados sob essa visão "sócio-ambiental". Isso ocorreu com a proposição de um novo modelo, chamado de desenvolvimento sustentável, que busca uma composição entre os fatores econômico, social e ambiental. Na implementação do desenvolvimento sustentável, os interesses que eram conflitantes e excludentes agora necessariamente precisam ser compostos. Um exemplo da observação das questões ambientais sob a ótica dos conflitos, é o Distrito Federal e sua Região Integrada de Desenvolvimento Econômico - RIDE, cuja população expandiu com a implementação fragmentada de projetos de uso e ocupação do território. Nesse contexto, o presente trabalho buscou explicar a dinâmica e a expressão espacial de um conflito sócio-ambiental ocorrente na micro-bacia do Rio Samambaia, no DF. Palco de uma intensa ocupação territorial em um curto espaço de tempo, promovendo uma rápida mudança da paisagem, hoje as conseqüências dessa drástica mudança. Com a presente pesquisa, percebeu-se que esse modelo de ocupação do território não difere de outras unidades semelhantes no DF, em face à urbanização acelerada e as Revista Eletrônica: Tempo - Técnica - Território, V.3, N.1 (2012), 86:124 ISSN: 2177-4366 
ausências e incongruências nas políticas públicas estatais para a demanda habitacional. Ficou evidente que a dificuldade de acesso à terra por meios legais estimula parte da sociedade a buscar outros mecanismos, por vezes ilícitos, para satisfazer sua demanda habitacional. Esse fato associado à ineficaz gestão territorial por parte do Estado e somado a processos migratórios e à especulação imobiliária, fomentam o comprometimento ambiental e a eclosão de conflitos sócio-ambientais na micro-bacia do Rio Samambaia. Como principais atores do conflito encontrou-se moradores, o governo do Distrito Federal e a União, ambos com seus distintos órgãos. Para a busca de soluções sugere-se mecanismos de diálogo/cooperação, buscando-se consenso. Percebeu-se que nesse conflito envolvem-se atores de diversas vertentes, com relações assimétricas de poder.

Palavras-chave: uso do território, crescimento urbano, conflito sócio-ambiental, bacia de drenagem, gestão do território, rio samambaia, Distrito Federal

Abstract: The environmental thematic subject can also be seen under the optics of the conflict, since the natural resources are be objects of disputes and interests. The subjects of the environment can be classified according to types different from conflict and they elapse of the dispute or misunderstanding related with the exploration of the natural resources, tending to increase with the shortage and competition for the natural resource. In the end of the century 20 the conflicts related with environment began to be studied under that environmental vision. That happened with the proposition of a new model, call of maintainable development that looks for a composition among the factors economical, social and environmental. In the concept of the maintainable development, the interests that were in conflict now they necessarily need to be composed. An example of the observation of the environmental subjects under the optics of the conflicts, is Distrito Federal (DF) a Brazilian state and it's Integrated Area of Economical Development, whose population expanded without projects for use and occupation of the territory. The present work explains the dynamics and the space expression of a environmental conflict Samambaia's stream, in DF. Stage of an intense territorial occupation in a short space of time, promoting a fast change of the landscape and the consequences of that drastic change. With to present researches, it was noticed that model of occupation of the territory doesn't differ of other similar units in DF, in face to the accelerated urbanization and the absences and incongruities in the state public politics for the habitation demand. It was evident that the access difficulty to the earth for legal means stimulates part of the society to look for other mechanisms, for illicit times, to satisfy your habitation demand. That fact associated to the ineffective territorial administration by the part of the Brazilian State and added to migratory processes and the real estate speculation, they foment the environmental compromising and the appearance of environmental conflicts in the Samambaia's. As main actors of the conflict met residents, the DF government and the 
Brazilian government, both with your different organs. For solutions it is suggested cooperation mechanisms, being looked for consent. It was noticed that wrap up actors of several slopes in that conflict, with asymmetric relationships of being able to.

Word-key: territory use, urban growth, environmental conflict, drainage water basin, territory administration, samambaia stream, Distrito Federal

Resumen: Las cuestiones medioambientales también puede verse bajo las ópticas del conflicto, desde que los recursos naturales son objetos de disputas e intereses. Los asuntos del ambiente pueden ser clasificados según los tipos diferente del conflicto y ellos pasan de la disputa o entendiendo mal relacionaron con la exploración de los recursos naturales, mientras tendiendo a aumentar con la escasez y competición para el recurso natural. En el fin del siglo 20, los conflictos relacionados con el ambiente empezaron a ser estudiados bajo esa visión medioambiental. Eso pasó con la proposición de un nuevo modelo, llamado de desarrollo sustenible que busca una composición entre los factores sociales y medioambientales. En el concepto del desarrollo sustenible, los intereses que estaban ahora en el conflicto que ellos necesariamente necesitan ser compuestos. Un ejemplo de la observación de los asuntos medioambientales bajo las ópticas de los conflictos, es Distrito Federal (DF) un estado brasileño y Área de Desarrollo Económico, cuya población extendió sin los proyectos para el uso y ocupación del territorio. El trabajo presente explica la dinámica y la expresión espacial de un conflicto medioambiental em el arroyo de Samambaia, en DF. La fase de una intensa ocupación territorial en un espacio corto de tiempo, promoviendo un cambio rápido del paisaje y las consecuencias de ese cambio drástico. En esse proceso, fue notado que modelo de ocupación del territorio no difiere de otras unidades similares en DF, con urbanización acelerada y las ausencias e incongruencias en la política pública estatal para la demanda de la habitación. Era evidente que la dificultad de acceso a la tierra por medios legales estimula parte de la sociedad para buscar otros mecanismos, para satisfacer su demanda de la habitación. Ese hecho asoció a la administración territorial ineficaz por la parte del Estado brasileño y agregó a los procesos migratorios y la especulación de tierras. Eso fomenta factores de conflictos medioambientales en el Arroyo Samambaia's. Como los actores principales del conflicto existem los residentes, el gobierno de DF y el gobierno brasileño, ambos con sus órganos diferentes, se encontraron. Para las soluciones se hace pensar en mecanismos de cooperación, pareciéndose para el consentimiento. Fue notado que la envoltura a actores de varias cuestas en ese conflicto, con las relaciones asimétricas.

Palabra clave: uso del territorio, el crecimiento urbano, conflicto medioambiental, cuenca, administración del territorio, Arroyo Samambaia, Distrito Federal 


\section{Introdução}

O Distrito Federal, com uma área de $5.814 \mathrm{~km} 2$ e uma população de aproximadamente 2.000 .000 de habitantes (CODEPLAN, 2006) está situado numa região de terras altas que servem como dispersores das drenagens que fluem para quatro importantes bacias fluviais do Brasil: Prata, Araguaia, Tocantins e São Francisco. Encontra-se totalmente inserido no Bioma Cerrado, um dos mais ricos em biodiversidade do planeta, sendo que $40 \%$ de seu território estão inseridos na Reserva da Biosfera do Cerrado, criada pela Unesco no espírito do programa "Homem e a Biosfera". (UNESCO, 2000)

No período de 1980 - 2000, em virtude do forte crescimento populacional e da intensificação das atividades econômicas no setor agropecuário e de serviços no Distrito Federal, verifica-se uma forte pressão sobre os recursos naturais, colocando-se em risco seu uso sustentável.

A manutenção da sustentabilidade do desenvolvimento regional deverá, cada vez mais intensamente, pautar-se pela garantia do equilíbrio entre as ações voltadas para a promoção do crescimento econômico e a conservação do meio ambiente.

Desta forma, há a necessidade de mudanças de alguns paradigmas do desenvolvimento, tais como, a procura de racionalização e a otimização desses recursos ambientais, planejada ocupação territorial e busca da diminuição das desigualdades sociais. Até 1998 , o Distrito Federal havia perdido mais de $75 \%$ de sua cobertura original de cerrado e $25 \%$ das áreas de mata (UNESCO, 2000).

Atualmente no Distrito Federal, já são perceptíveis situações de graves conflitos ambientais quanto à ocupação do território e recursos hídricos, que já assumem proporções preocupantes.

Uma das localidades que é modelo de expressão desse fato é a Bacia do Rio Samambaia. Esta sofreu a partir da década de 60, um processo de ocupação desordenado e que culmina atualmente com um palco ou arena de confronto de atores envolvidos em distintos posicionamentos e ações, no que se refere à demanda por recursos naturais, aspectos fundiários e também políticos.

$\mathrm{Na}$ esfera distrital, percebe-se que o governo local não tem conseguido conter as ocupações irregulares. As agressões ambientais decorrentes desse modelo continuam ocorrendo. Condomínios irregulares proliferam e o processo de legalização não tem conseguido alcançar consenso entre os envolvidos. Os proprietários e moradores enquanto aguardam uma posição do governo constroem edificações sem orientação ou planejamento, por vezes em áreas de risco. Os problemas aparecem, desmatamento de rios e nascentes, contaminação de lençol freático e doenças. Diante das irregularidades e da possibilidade de perder o 
investimento, proprietários aceleram a ocupação e promovem uma degradação ambiental cada vez maior. O governo reage com demolições pontuais.

O presente estudo tem como objetivo principal identificar e analisar espacialmente os componentes estruturais dos conflitos sócio-ambientais existentes no processo de ocupação e transformação territorial da micro-bacia do rio Samambaia, no Distrito Federal. A matriz dessa análise sócio-ambiental baseia-se em critérios fundiários, políticos e culturais e também em características físicas da bacia hidrográfica, tais como vegetação e a hidrografia. É justamente o cruzamento dessas informações, associado à temporalidade do processo de ocupação e transformação territorial, que fornece o panorama do conflito. Vale ressaltar a escolha da Bacia Hidrográfica como unidade de análise geográfica já que esta possibilita uma gestão estruturada pela interação de condições físicas da área e pelas condições sócioeconômicas e culturais da população que ela abriga. A bacia em questão situa-se no principal eixo de desenvolvimento do Distrito Federal, que é a região entre Taguatinga e o Plano Piloto. Os procedimentos metodológicos desenvolvidos para a investigação buscam o entendimento do modelo de conflito, seus processos e atores podem servir como referencial de base para outros estudos dessa natureza no DF e no Brasil Central.

A metodologia deste trabalho é estruturada em duas partes básicas e conexas. A primeira refere-se ao estudo e caracterização do uso do território na bacia hidrográfica em escala multitemporal e a segunda na identificação espacial de componentes estruturais e atores de conflito presentes na bacia hidrográfica. A análise integrada das informações das duas etapas permitirá a caracterização do conflito sócio-ambiental. A referência é que este estudo seja também uma contribuição para processos de origem e dinâmica de conflitos sócio-mbientais, mediante um estudo de caso. Foi efetuado um levantamento de dados sobre o uso multi-temporal do território na bacia hidrográfica para conhecer as características e condições ambientais e juntamente com as condições socioeconômicas e legais, constituir a base para a elaboração e caracterização do conflito em questão. Buscou-se com isso fundamentar medidas que possam auxiliar na conservação dos recursos naturais dessa localidade e conciliar estes com a ocupação humana.

Com isso buscou-se entender os resultados da adoção de soluções pontuais para solucionar os problemas territoriais no DF, as quais geram impasses diante da realidade de demandas habitacionais não atendidas e que acaba por estimular a irregularidade como modelo de ocupação territorial. Os produtos finais de monitoramento da ocupação territorial, carta síntese dos conflitos, possibilitam sugestões à comunidade e ao setor decisório buscando apresentar alternativas para compatibilizar expansão urbana com a preservação do meio natural local.

\section{Principais Conceitos e Procedimentos Metodológicos}

\subsection{O Conceito de Território}

A palavra território refere-se a uma área delimitada sob a posse de uma pessoa (ou grupo de pessoas), de uma organização ou de uma instituição. O termo é 
empregado na política referindo-se ao Estado Nação. Há vários sentidos figurados para a palavra território, mas todos compartilham da idéia de apropriação de uma parcela geográfica por um indivíduo ou uma coletividade. Em geopolítica, também se usa o termo "território" para identificar estados não independentes e subordinados, até certo grau, a um poder externo. Existem diferentes categorias de território, de acordo com as relações de dependência. (CORRÊA \& ROSENTHAL, 1998).

Dessa maneira pode-se entender o território como a manifestação espacial do poder fundamentada em relações sociais em diferentes graus, pela presença de ações e estruturas concretas e de informação. Essa compreensão permite pensar o processo de territorialização-desterritorialização-reterritorialização, baseado, sobretudo, no grau de acessibilidade à informação; em outras palavras, a informação, ou não, de símbolos e/ou de significados podem fazer surgir novos territórios (territorialização), destruí-los (desterritorialização) ou reconstruí-los (reterritorialização) (RAFFESTIN 1993).

\subsection{Paisagem}

Em uma visão clássica, paisagem é a expressão materializada das relações do homem com a natureza num espaço circunscrito (SCHIER, 2003). Entretanto, a paisagem, é algo além do visível, resultante de um processo de articulação entre seus elementos constituintes, sejam eles de ordem exclusivamente natural (paisagens naturais) ou de ordem humana (paisagens culturais) (TROLL, 1982).

Contemporaneamente, Milton Santos nos trás a paisagem como sendo a expressão materializada do espaço geográfico, definindo-a como "o conjunto de formas que, num dado momento, exprimem as heranças que representam as sucessivas relações localizadas entre o homem e a natureza". Santos diferencia paisagem de espaço: onde aquela é "transtemporal" juntando objetos passados e presentes, uma construção transversal juntando objetos e este é sempre um presente, uma construção horizontal, uma situação única. Ou ainda, paisagem é um sistema material, nessa condição, relativamente imutável, espaço é um sistema de valores, que se transforma permanentemente (SANTOS, 1997).

Diante desses fundamentos, percebe-se que a paisagem pode ser analisada como a materialização das condições sociais, onde poderão persistir elementos naturais, embora já transfigurados (ou natureza artificializada). O conceito de paisagem privilegia a coexistência de objetos e ações sociais na sua face econômica e cultural manifesta, percebendo-a como um processo de constituição e reconstituição de formas na sua conjugação com a dinâmica social (SCHIER, 2003).

\subsection{Conflitos Sócio-Ambientais: Fundamentação e Conceitos}

O campo dos conflitos sócio-ambientais representa uma realidade e seu estudo responde a uma demanda urgente da definição de ações e intervenções nas decisões que determinam como uma sociedade satisfaz suas necessidades. Assim, compreender os conflitos na construção social da realidade é importante para o conjunto da sociedade na formulação de políticas que reflitam o estágio histórico das lutas sociais de vários segmentos. (LITTLE, 2001)

Revista Eletrônica: Tempo - Técnica - Território, V.3, N.1 (2012), 86:124 ISSN: 2177-4366 
Atualmente os conflitos são entre o espaço político-institucional nacional e o espaço econômico mundial e entre a desigualdade econômica com o espaço político da igualdade. Existem enormes discrepâncias na distribuição de riquezas em contraponto a uma relativa igualdade de direitos políticos, como por exemplo, no sistema eleitoral, onde cada pessoa rica ou pobre é única e autônoma para escolher seus mandatários. A emergência dos conflitos ambientais ocorre à medida que se aprofunda o processo de transformação econômica e social dos territórios, pondo em evidência a disputa por hegemonia entre distintas concepções sobre a forma de incorporação da natureza e do meio ambiente para satisfazer necessidades materiais e simbólicas das comunidades. Na realidade de um mundo globalizado, se o mercado crias desigualdades, o Estado, personificado periodicamente pelos elegidos no processo eleitoral, busca controla-las ou mitiga-las. É nessa dinâmica de global versus local e igual versus desigual que se tem a modernidade ocidental. (LITTLE, 2001)

Para Little, 2001 o conceito de conflitos sócio-ambientais é: "disputa entre grupos sociais derivadas dos distintos tipos de relação que eles mantêm com seu meio natural". São embates entre grupos sociais, em função de seus distintos modos de inter-relacionamento ecológico, com seus respectivos meios social e natural.

Quando se estuda conflitos é importante lembrar que os objetos de disputa não são necessariamente apenas matéria e energia, mas também emanam aspectos culturais e históricos. Todos os objetos e do ambiente, as práticas sociais os usos e sentidos atribuídos ao meio interagem materialmente e socialmente pelas águas pelo solo ou atmosfera. É a apropriação do mundo resultado da relação entre espacialidade geográfica, organização ecológica e significação cultural.

Com essa discussão, evolui-se para a questão do território e/ou territorialidade, que um processo de domínio político e econômico e de apropriação simbólico ou cultural do espaço pelos grupos humanos. E quando se apropria de um espaço de maneira concreta ou abstrata o ator territorializa este. (LITTLE, 2001; BASTOS, 2006)

Segundo Leff, 2001 as sociedades se reproduzem por processos sócio-espaciais e ecológicos que definem a territorialidade de uma cultura, a espacialidade de uma sociedade, onde se constituem os sujeitos sociais que projetam o espaço geográfico apropriando-se dele, habitando com suas significações e práticas. Segundo o autor, a definição de território diz respeito a uma territorialidade construída por práticas de apropriação do mundo, resultado da relação entre espacialidade geográfica, organização ecológica e significação cultural.

Haesbaert (2004) destaca que o território caracteriza-se por ser um processo de domínio político-econômico ou de apropriação simbólico-cultural do espaço pelos grupos humanos mediante o imaginário e identificação social sobre o espaço. Raffestin 1993, considera que o espaço deve ser compreendido como anterior ao território, pois o território é caracterizado pelas relações sociais e o espaço pressupõe a ausência desses aspectos. Dessa forma, ao se apropriar de um espaço, concreta ou abstratamente, o ator territorializa o espaço. O mesmo autor afirma que um território é um espaço modificado pelo trabalho e que revela relações de poder, fundamentais para a compreensão do território em seu caráter político. Para esse autor a territorialidade pode ser vista como a tentativa de um indivíduo ou grupo social de 
influenciar, controlar pessoas, recursos, fenômenos e relações, delimitando e efetivando o controle sobre uma área.

Diante do exposto, o meio urbano faz parte dessa dinâmica já que se estabelece uma intrincada rede de relações e disputas de poder no uso e ocupação territorial, seja pela gestão das águas, dos solos, do acesso à infra-estrutura urbana entre outros. Deste ponto de vista, pode-se considerar as lutas por recursos ambientais como também lutas em sentidos culturais.

\section{Caracterização Geográfica da Micro-Bacia do Rio Samambaia e seus Conflitos Sócio-Ambientais.}

Bacia hidrográfica é uma unidade geográfica que se constitui de um espaço de terreno limitado pelas partes mais altas do relevo, com um sistema de drenagem superficial que concentra suas águas em um sistema fluvial. São distintos quanto sua forma e estrutura, fator esse que caracteriza sua aptidão, potencial, limitações e problemas. Uma bacia estrutura-se por sua interação de condições físicas, climáticas e topográficas da área e pelas condições sócio-econômicas e culturais da população que ela abriga. (FAUSTINO, 1996)

Dessa maneira, ela pode ser encarada como um sistema cuja magnitude das inter-relações irá definir o nível de complexidade e o grau de sobreposição dos subsistemas entre si e também o grau de conflito dos diferentes interesses concorrentes no sistema. A bacia hidrográfica é, portanto, uma interação de solo, água, vegetação e fauna que coexiste com interferências naturais (intemperismo e modelagem da paisagem) e aquelas de natureza antrópica (uso/ocupação da paisagem). Neste sistema os recursos hídricos servem de indicadores dos efeitos do desequilíbrio das interações dos respectivos componentes. Por esse motivo bacias e sub-bacias hidrográficas vêm-se consolidando como compartimentos geográficos coerentes para planejamento integrado do uso e ocupação dos espaços, sejam rurais e urbanos, tendo em vista o desenvolvimento sustentado no qual se compatibilizam atividades econômicas com qualidade ambiental (SOUZA e FERNANDES, 2000).

A bacia caracteriza-se, então, como um espaço onde a delimitação física antepõe-se à delimitação política, sendo esta, porém, a que define esse espaço socialmente, dando-lhe a conotação mais apropriada de um território. Analisados esses fundamentos, pode-se entender melhor a dinâmica da região de estudo do presente trabalho.

A micro-bacia hidrográfica do Rio Samambaia abriga a colônia agrícola Samambaia, cujos moradores são principalmente de classe média, Vicente Pires, onde encontram-se as pessoas de renda mais elevada, e a Vila São José, composta principalmente por pessoas menos favorecidas, que juntas formam o chamado "Setor Habitacional Vicente Pires" (Figura 1). As terras dessa micro-bacia pertencem à TERRACAP e União/Secretaria de Patrimônio da União/SPU. A questão fundiária é ainda polêmica, pois os dois órgãos estatais ainda não se definiram na parte que pertence a cada um dele.

A área da micro-bacia é de aproximadamente 20.000.000 $\mathrm{m}^{2}$ localizando-se na região administrativa de Taguatinga. Situa-se na bacia hidrográfica do Lago Paranoá, mais especificamente na unidade hidrográfica do Riacho Fundo e sua área de 
influência direta é delimitada a oeste pela área destinada a construção do TAGUAPARK, a sul pela Estrada Parque Taguatinga (EPTG) - DF 085-, a leste pelo rio Vicente Pires e a norte pela Estrada Parque Ceilândia (EPCL) - DF 095- (Via Estrutural).

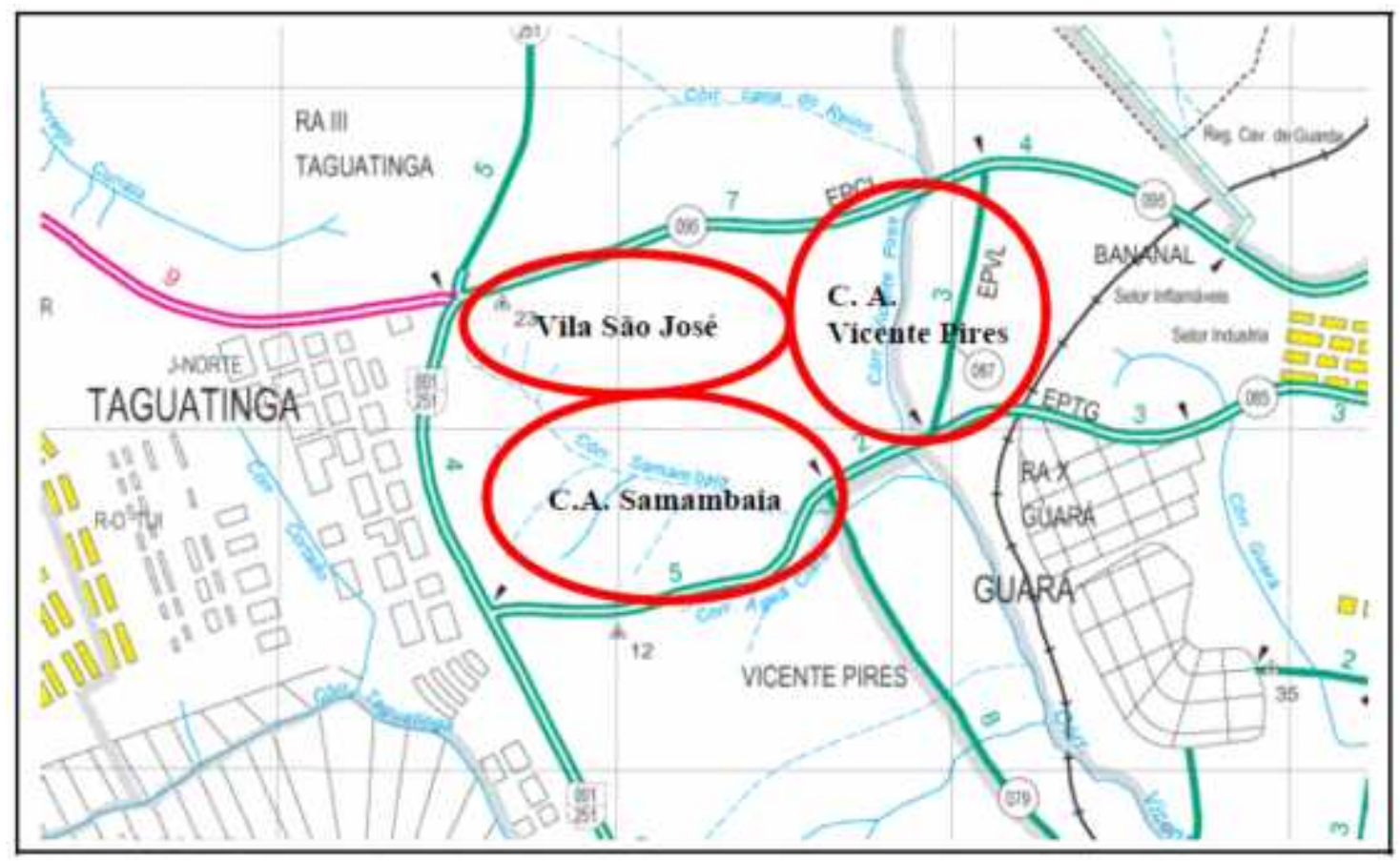

Figura 1 - Localização da região de estudo.

O Rio Samambaia é tributário do rio Vicente Pires e esses dois nascem e atravessam toda a área do Setor Habitacional Vicente Pires. A unidade hidrográfica do Riacho Fundo, contribuinte do Lago Paranoá, possui uma área de $228,3 \mathrm{~km}^{2}$ e a extensão de seu curso principal é de 13 quilômetros, cujos principais afluentes do Riacho Fundo são os rios Vicente Pires e Guará, pela margem esquerda, e o rio Ipê, pela margem direita.

\subsection{Contextualização Histórica e Ocupação do Território}

A história da ocupação territorial desta micro-bacia remonta a década de 60 onde o presidente Juscelino Kubitscheck estimulou a migração e alocou algumas famílias de agricultores, entre eles japoneses, que moravam às margens dos rios nas regiões ocupadas por Taguatinga, Samambaia e Águas Claras, para a Fazenda Brejo Torto. No governo José Ornelas, em meados de 1984, ocorreu uma tentativa de desocupação da região, que estimulou os moradores da região a mobilizarem-se elegendo Jorge Cahuí como seu interlocutor diante do GDF, buscando resolver a problemática em uma reunião com autoridades governamentais em busca de uma alternativa que não implicasse na remoção das famílias da localidade. Dessa situação surgiu a Associação dos Produtores Rurais do Projeto Águas Claras - APROAC. A luta da população local pela manutenção de sua permanência na região levou à criação da proposta de criação de colônias agrícolas mantendo-se sua vocação agrária.

Em 1986, o Governo do Distrito Federal autorizou a ocupação criando o Projeto Águas Claras. O Conselho de Arquitetura, Urbanismo e Meio Ambiente (CAUMA)

Revista Eletrônica: Tempo - Técnica - Território, V.3, N.1 (2012), 86:124 ISSN: 2177-4366 
deveria aprovar previamente o Projeto onde o levantamento e divisão da área foram realizados pela Fundação Zoobotânica do Distrito Federal (FZDF).

Em meados da década de 1980, iniciou-se, lentamente, o processo de ocupação daquelas colônias agrícolas por habitações com características urbanas, que viriam substituir gradativamente a produção rural.

$\mathrm{Na}$ década de 1990, esse processo de parcelamento do solo foi intensificado, oportunidade em que muitos cessionários, ao invés de cumprirem fielmente os termos pactuados nos respectivos contratos de concessão de uso e plano de utilização, decidiram fracionar aquelas terras públicas e comercializá-las, com lucro próprio, para fins de loteamento com características urbanas sem o mínimo planejamento urbano.

O fato da implementação das cidades do Guará (1969), Ceilândia (1971), e Samambaia (1985), como satélites estimula a idéia de que a região de Vicente Pires teria a vocação de uso rural e integraria um "cinturão verde", que envolveria o Plano Piloto e as demais áreas urbanas e prestando-se a manter padrões de qualidade ambiental para a bacia do Paranoá.

Todavia, foi o próprio surgimento dessas novas cidades satélites e o seu conseqüente adensamento, estimulado pela estrutura de segregação social-espacial, nos custos e inconvenientes dos deslocamentos casa-trabalho, e solucionar os problemas de deslocamento pendular da população em direção ao Plano Piloto, foram planejadas e construídas as primeiras linhas de metrô. Percebeu-se que com isso que a idéia do "cinturão verde" estava ficando superada e reforçou a tendência de estruturação de uma mancha urbana que se estende do Plano Piloto, passa pelo Guará, Águas Claras e chega a Taguatinga, Ceilândia e Samambaia.

\subsection{Uso e Ocupação do Território na Micro-Bacia do Rio Samambaia}

Como critério importante de análise do uso e ocupação territorial da microbacia do Rio Samambaia, foi efetuado o monitoramento em escala temporal, nos anos de 1964, 1976, 1981, 1989, 1998 e 2007, a delimitação da bacia e sua área e também se quantificou, em hectares, as classes de uso e ocupação do território, a saber: a) Floresta Ciliar; b) Urbano; c) Solo Exposto; d) Cerrado Sensu Strictu; e) Campo Cerrado.

A área total da micro-bacia estudada é de 1276 hectares. Percebeu-se uma modificação no uso e ocupação territorial ao longo da série histórica, que foram expressos em valores absolutos e também em porcentagem. Conforme as informações apresentadas são perceptíveis as mudanças na ocupação territorial original, de área agrícola para urbano. A maior presença de vegetação nativa de cerrado e vegetação ciliar, foi sendo paulatinamente sendo substituída por solo exposto, mediante o processo de desmatamento e fracionamento das chácaras originais para posterior processo de urbanização. Com o monitoramento e mensuração das classes de uso territorial esse processo é bem perceptível.

A título de facilitar o entendimento da dinâmica de transformação no uso e ocupação territorial na micro-bacia do Rio Samambaia foram também expressos em porcentagem, os valores encontrados no presente estudo. Compararam-se as áreas de 1964 com a dos anos subsequentes, e identificando o que aumentou e o que diminui no decorrer dos anos na bacia (Figura $2-6$ ).

Revista Eletrônica: Tempo - Técnica - Território, V.3, N.1 (2012), 86:124 ISSN: 2177-4366 


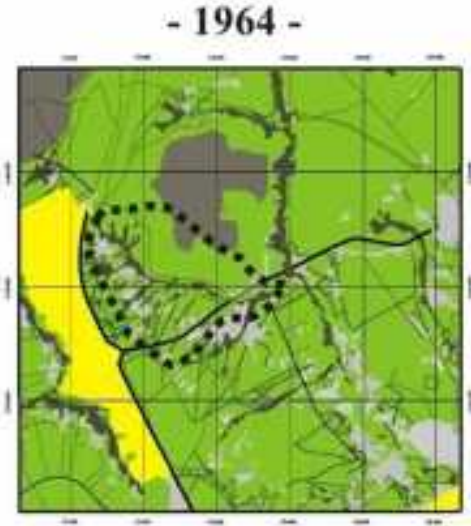

-1989 -

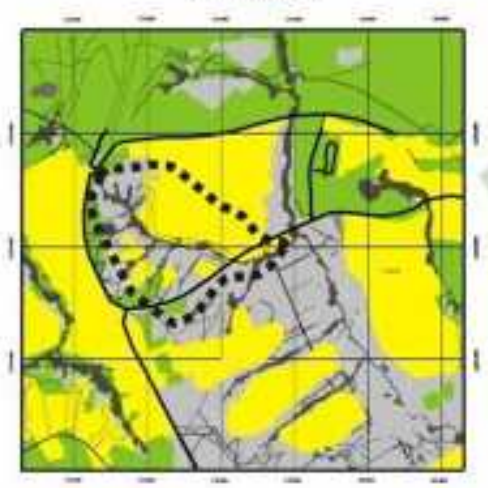

-1976 -

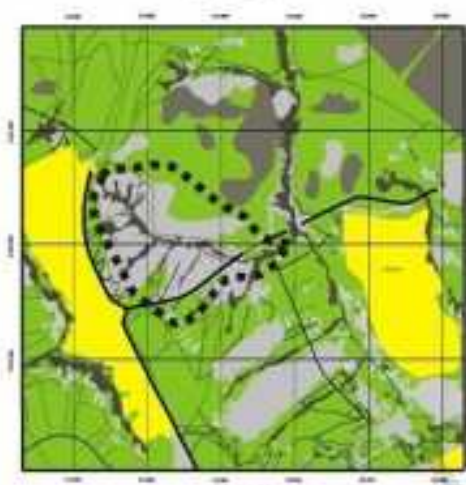

-1998 -

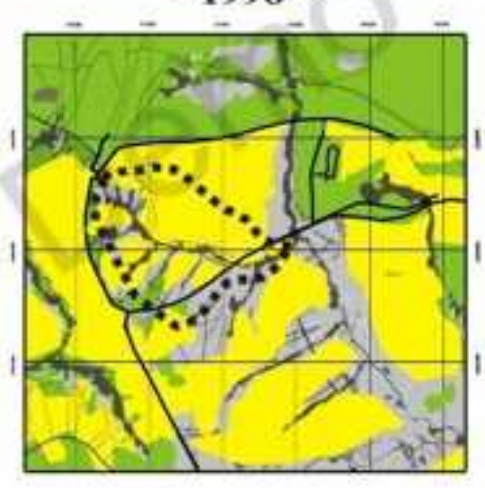

$-1981-$

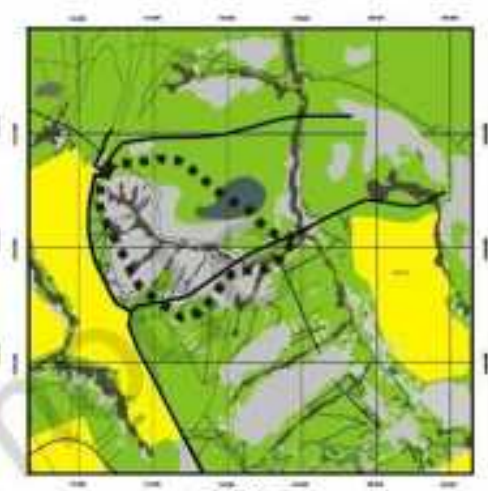

$-2007=$

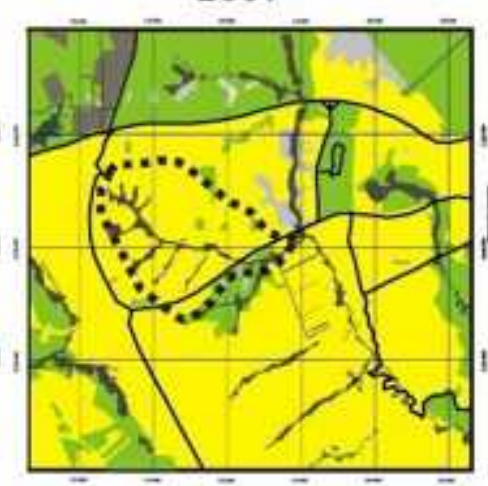

Figura 2 - Monitoramento Multitemporal da micro-bacia do Córrego Samambaia - 1964, 1976, 1981, 1989, 1998 and 2007.

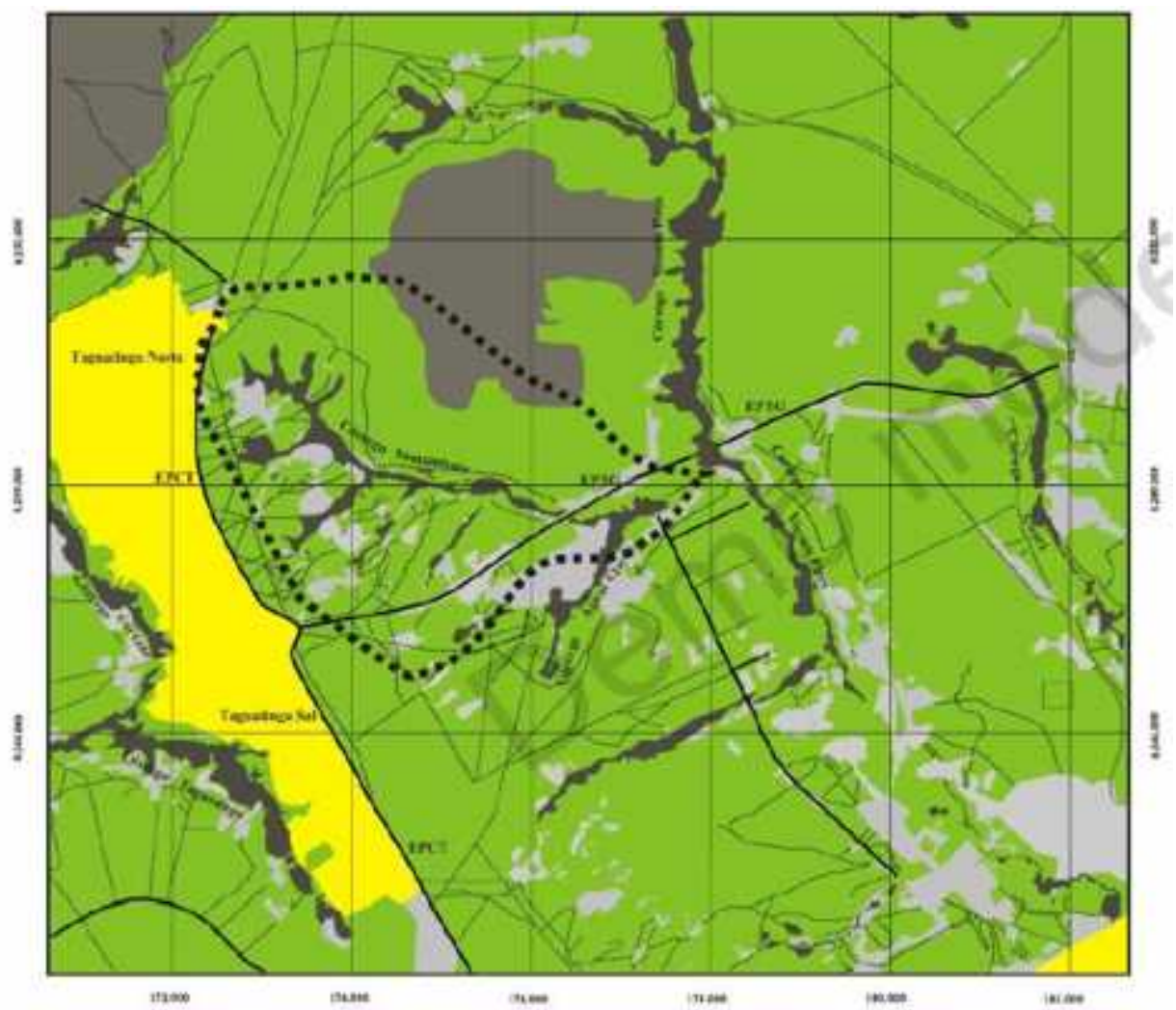

Figura 3 - Monitoramento Multitemporal da micro-bacia do Córrego Samambaia - 1964 


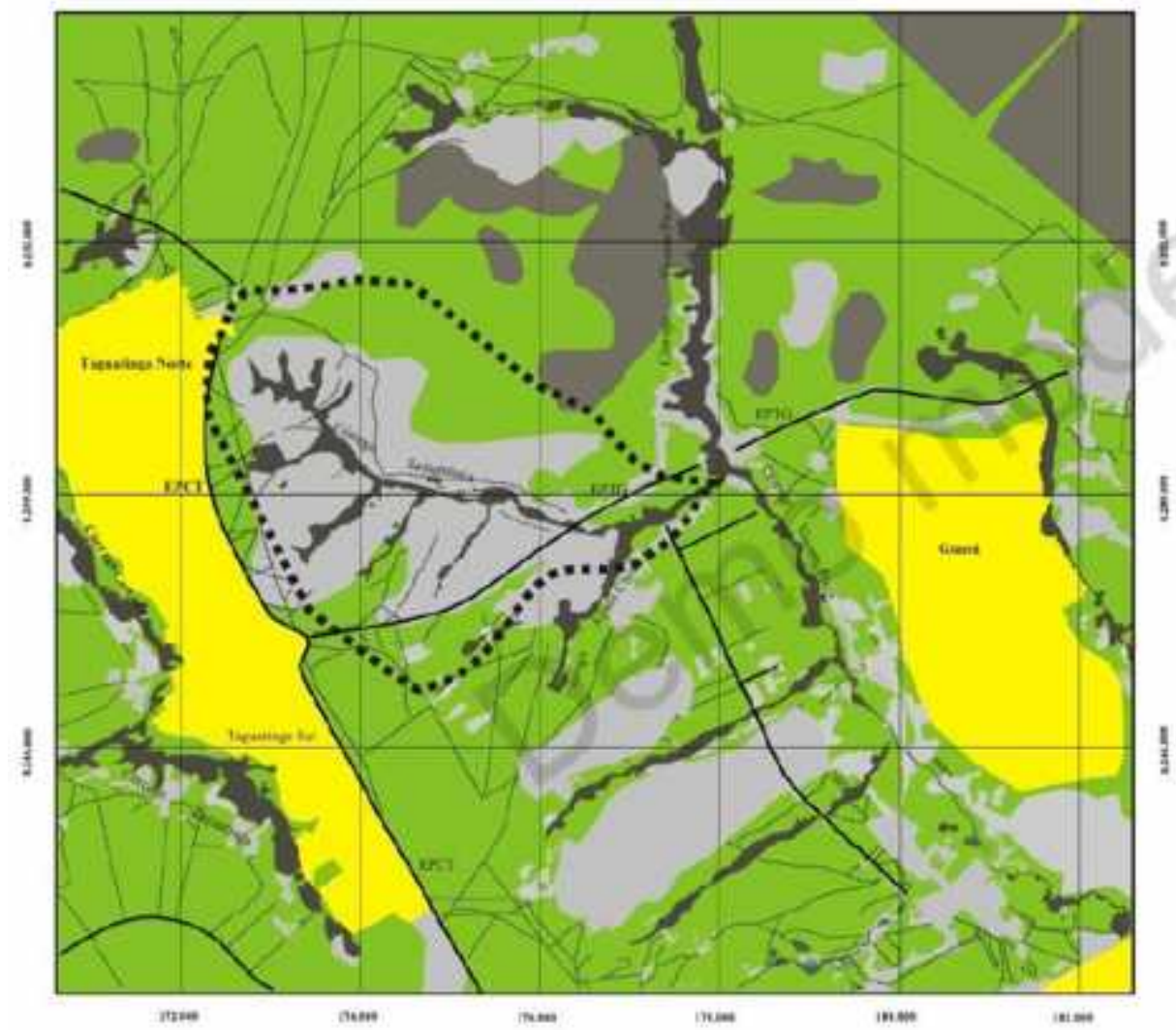

Figura 4 - Monitoramento Multitemporal da micro-bacia do Córrego Samambaia - 1976.

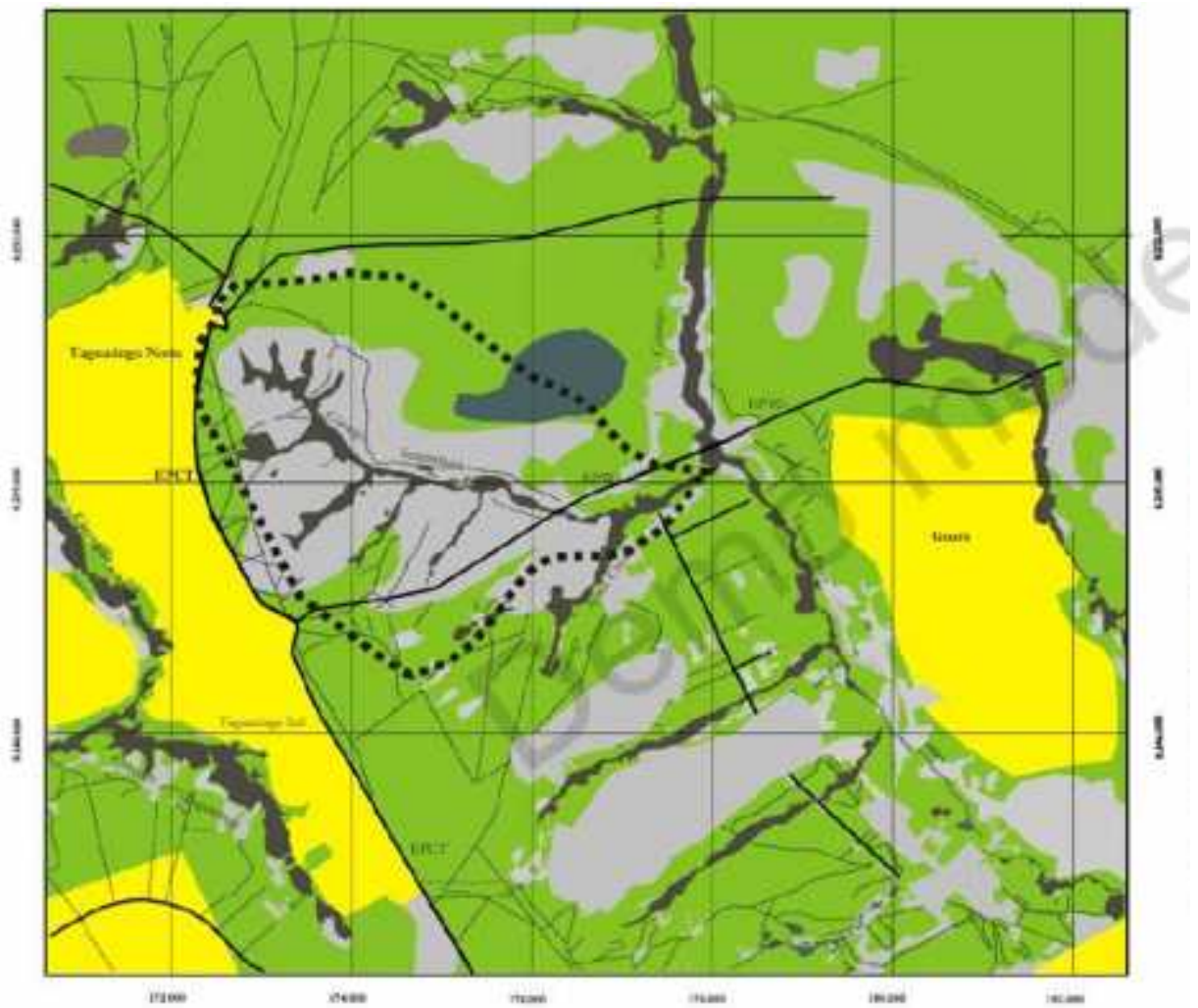

Figura 5 - Monitoramento Multitemporal da micro-bacia do Córrego Samambaia - 1981. 


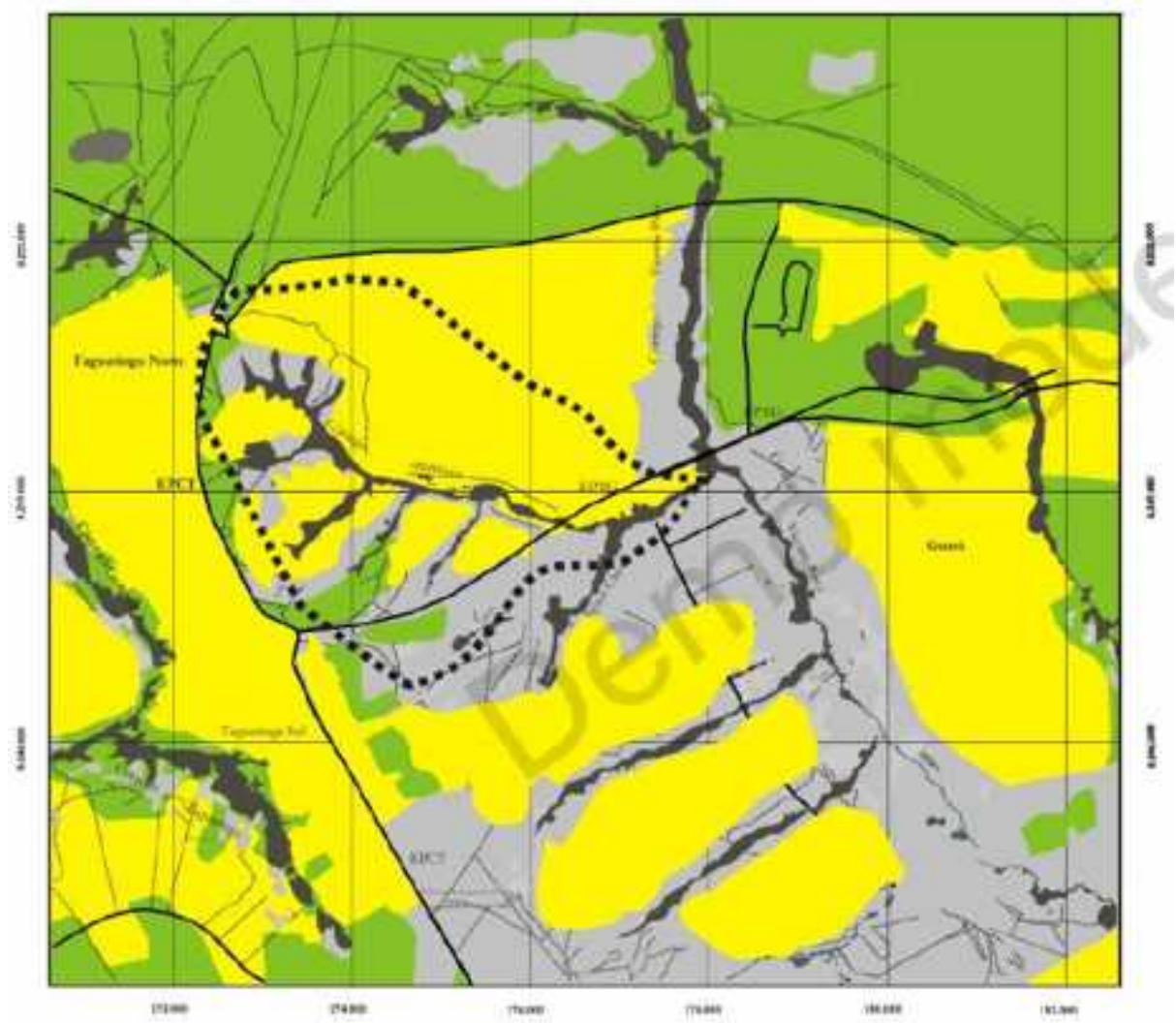

Figura 6 - Monitoramento Multitemporal da micro-bacia do Córrego Samambaia - 1989.

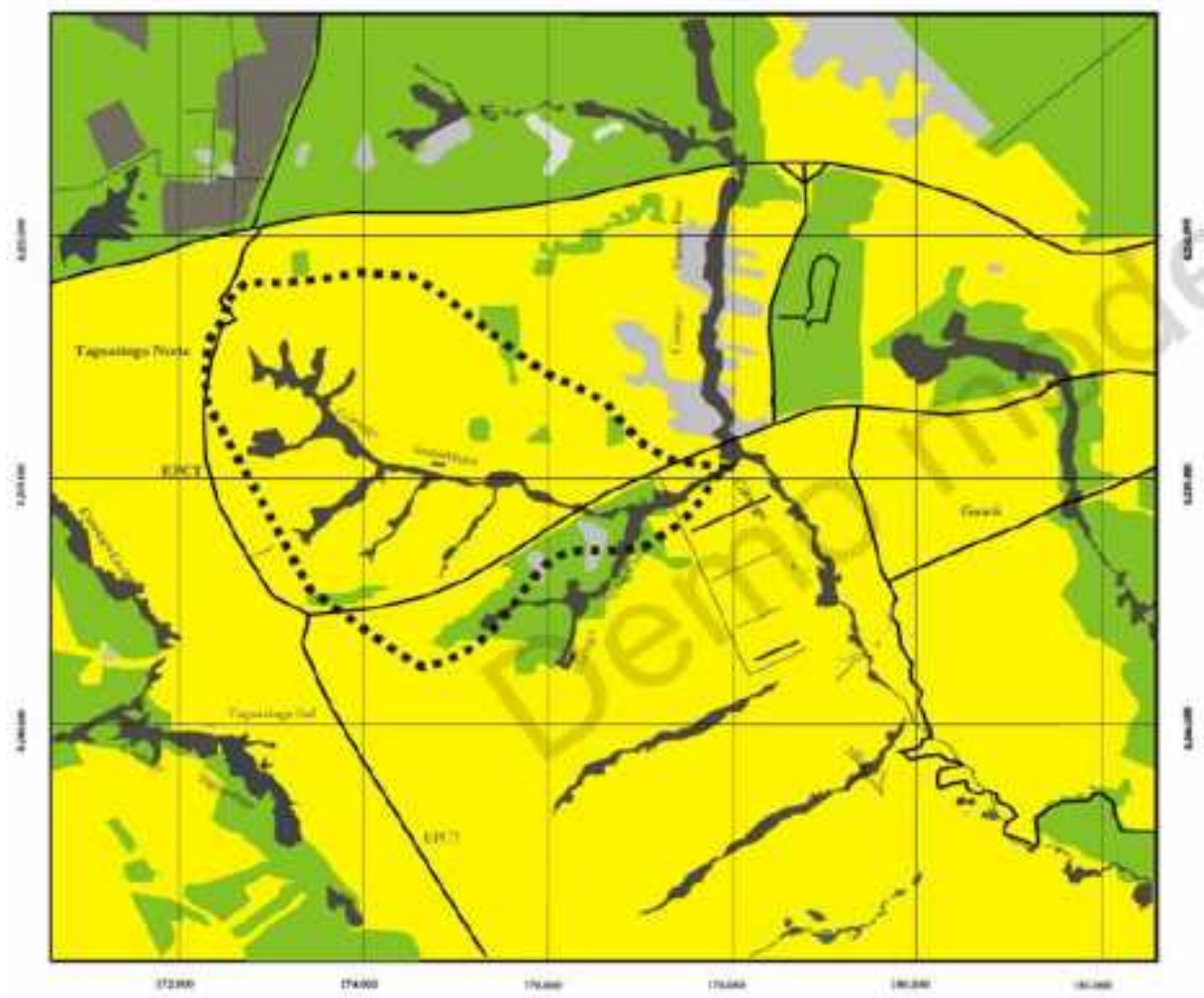

Figura 7 - Monitoramento Multitemporal da micro-bacia do Córrego Samambaia - 2007. 


\subsection{Florestal Ciliar}

Das fisionomias presentes na bacia a que menos sofreu modificação foi a floresta ciliar, e nem por isso menos intensa, reduzida em 50\% de 1964 até 2007. Nessa fisionomia percebe-se um processo constante e paulatino de redução dos 174 hectares originais em 1964, reduzindo-se para 145 hectares em 1976, 116 hectares em 1981. A partir de 1989 esse índice de perda decai, resultando em uma área de 101,5 hectares em 1989 e estabiliza-se em 1998 em 87 hectares, valor que permanece em 2007.

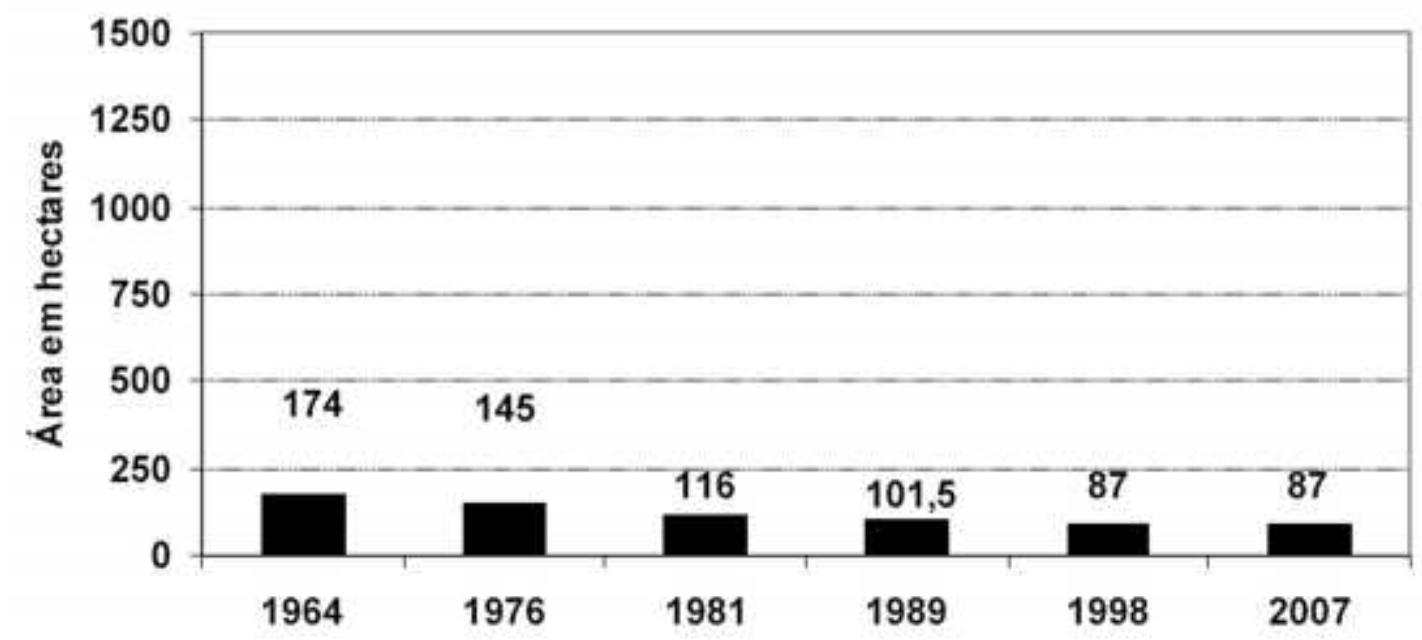

Figura 8 - Monitoramento Multitemporal da Floresta Ciliar na Microbacia do Rio Samambaia - 2007.

A floresta ciliar de 1964 a 1976, teve uma redução de 17\% em sua extensão. Em 1981, essa redução era de 33\%, em 1989 o nível de redução era de 42\%. Em 1998 a vegetação ciliar era de $50 \%$ da extensão encontrada no primeiro ano do monitoramento, valor que se manteve até 2007. Comparando-se o ano de 1964, ponto inicial do monitoramento, com a realidade atual de 2007, foi possível acompanhar a escala de redução da vegetação ciliar, que está na presente data com uma redução de $50 \%$ de sua extensão original.

\subsection{Campo Cerrado}

Nas áreas de campo cerrado, a redução da fisionomia foi maior. Em 1964 a extensão do campo cerrado era de 565,5 hectares com valores de 471,25 hectares em 1976 e 449,5 hectares em 1981. A partir de 1989 a redução dessa fisionomia se intensifica para valores de 275,5 hectares. De 1989 a 1998 essa fisionomia mantém a mesma extensão de área, para reduzir-se em 2007 para apenas 29 hectares, perfazendo uma perda de 95\% de sua formação original, em 1964. 


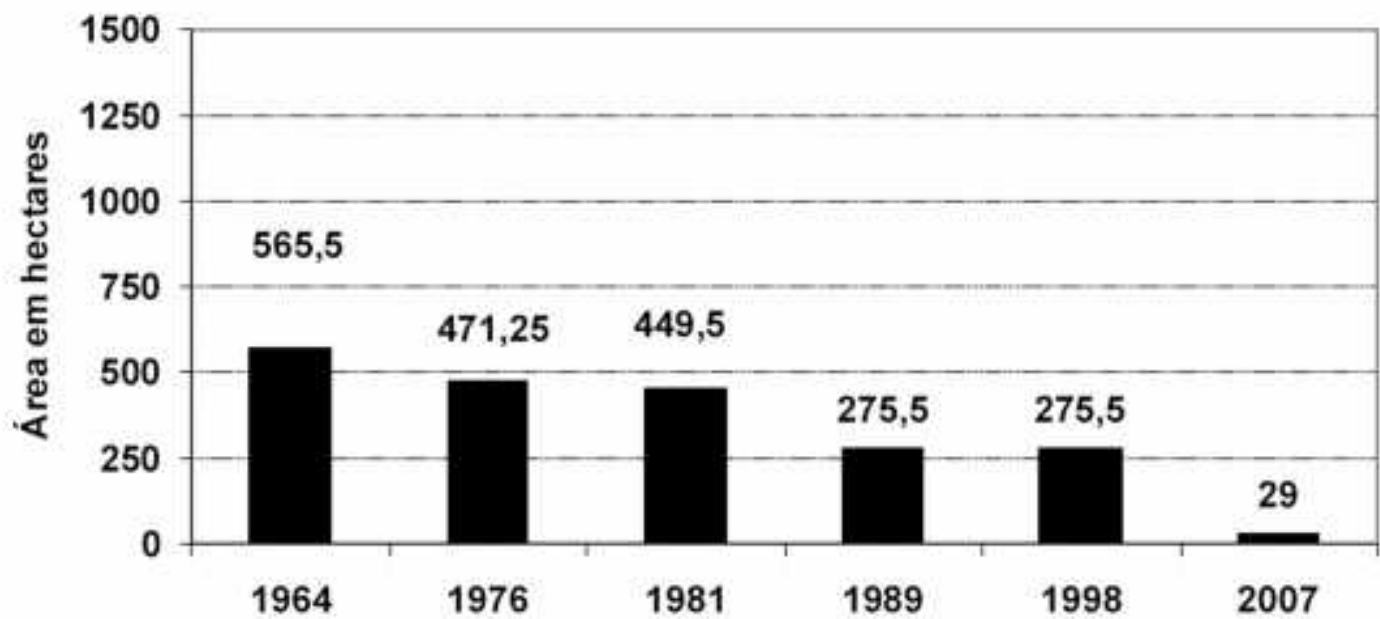

Figura 9 - Monitoramento Multitemporal da Floresta Ciliar na Microbacia do Rio Samambaia - 2007.

\subsubsection{Cerrado Sensu Strictu}

As áreas de Cerrado Sensu Strictu sofreram ainda mais com a intervenção antrópica na micro-bacia. Em 1964 sua extensão era de 290 hectares; reduziu-se para 188,5 em 1976; 87 em 1981 e entre 1981 e 1989 desapareceu da paisagem da microbacia, totalizando uma redução de $100 \%$ de sua formação original.

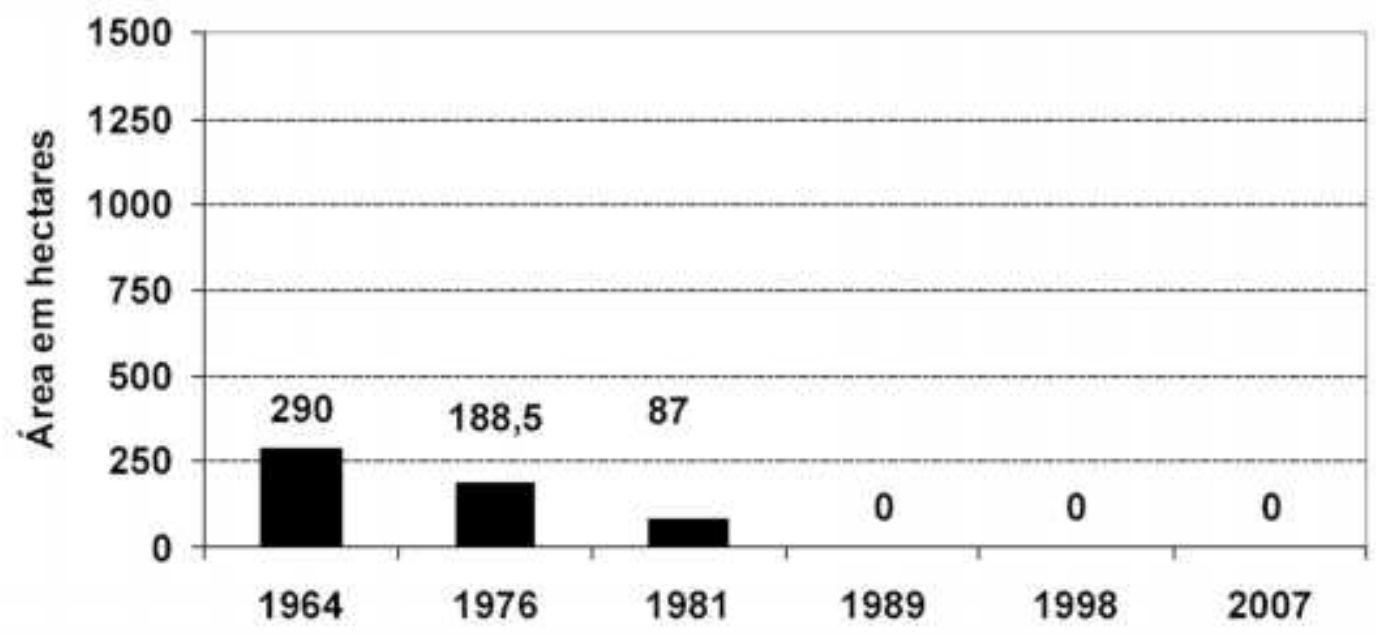

Figura 10 - Monitoramento Multitemporal de Cerrado Stricto na Microbacia do Rio Samambaia - 2007.

\subsubsection{Solo Exposto}

Com a intensificação da ocupação territorial, as áreas do chamado solo exposto tiveram um comportamento interessante, em 1964 eram de 166,75 hectares, aumentando em 1976 para 391,5 e em 1981 para 543,75. A partir de 1989, a área de solo exposto segue uma trajetória de queda, com valores neste ano de 384,25 hectares, em 1998 de 398,75 hectares e em 2007 de 29 hectares. E com o início da ocupação na micro-bacia a vegetação nativa era substituída pelas áreas de solo exposto, principalmente por atividades de chacareiros. Com o advento do parcelamento das chácaras em condomínios, essas áreas foram sendo substituídas por 
ocupações urbanas, daí a explicação de que em 2007 se tenha encontrado o valor de 27 hectares para essa classe.

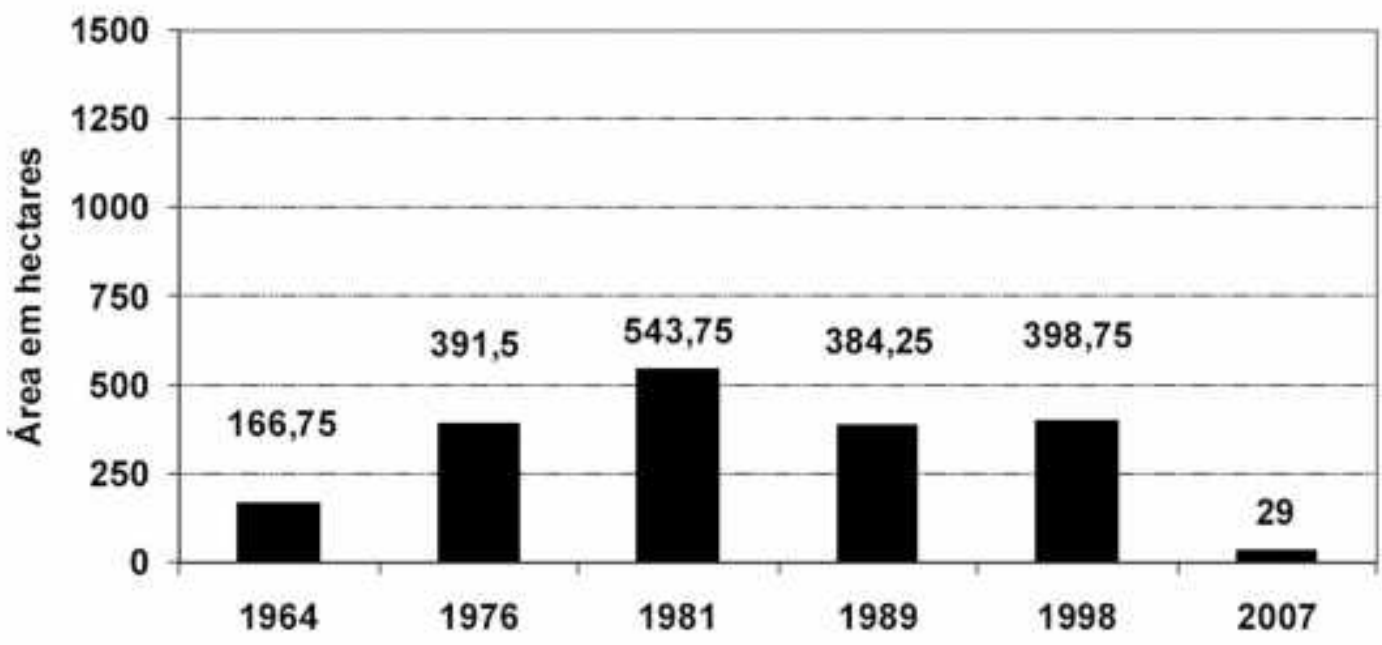

Figura 11 - Monitoramento Multitemporal de Cerrado Stricto na Microbacia do Rio Samambaia - 2007.

\subsubsection{Urbano}

No estudo do uso e ocupação territorial o fator da urbanização foi primordial na micro-bacia do Rio Samambaia, onde a expansão urbana pode ser considerada como explosiva. Entre 1964, 1976 e 1981 as áreas com ocupações urbanas eram de 79,75 hectares. Entre 1989 e 1998 esses valores aumentaram para 514, 75 e em 2007 valores de 1131 hectares, uma variação ao longo da série histórica de 1318\%.

O crescimento do urbano na micro-bacia, mostra bem como está foi ocupada e modificada sem critérios mínimos de sustentabilidade nem obediência aos instrumentos legais existentes. Em 1964, 1976 e 1981 a área urbana seguida com 79,75 hectares. Entre 1981 e 1989, os valores aumentam drasticamente, sendo em 1989 de 514, 75 hectares, em 1998, também de 514, 75 e em 2007 com o elevado valor de 1131 hectares.

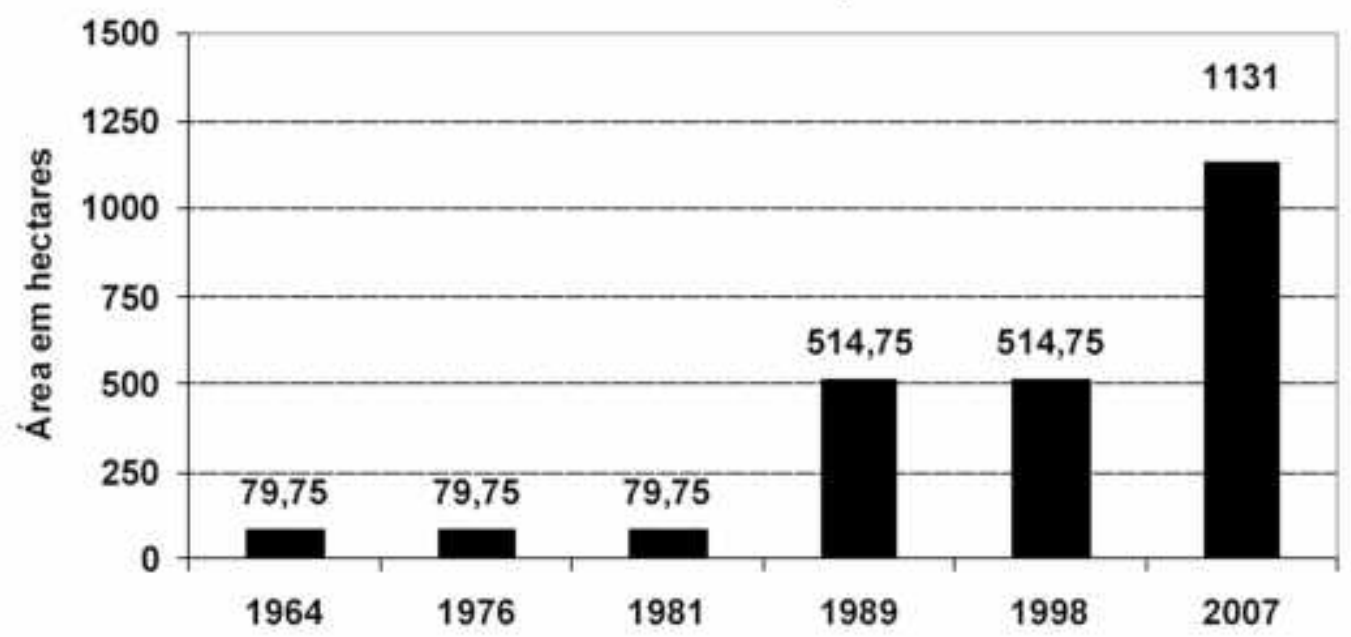

Figura 12 - Monitoramento Multitemporal de Cerrado Stricto na Microbacia do Rio Samambaia - 2007.

Revista Eletrônica: Tempo - Técnica - Território, V.3, N.1 (2012), 86:124 ISSN: 2177-4366 


\subsection{Quem mora na localidade? Uma Síntese do Perfil Sócio- Econômico dos Habitantes da Micro-Bacia do Rio Samambaia.}

Colaborando no entendimento da dinâmica dos conflitos sócio-ambientais na micro-bacia do Rio Samambaia, Maciel, (2001) em sua dissertação de mestrado desenvolveu uma pesquisa de campo buscando conhecer o perfil sócio-econômico dos moradores da micro-bacia do Rio Samambaia e também saber o que significa para essas pessoas morar nessa localidade. Em seu trabalho a micro-bacia foi divida em chácaras fracionadas e não fracionadas (chacareiros remanescentes). Uma síntese dos resultados da autora será aqui apresentada, de maneira a colaborar no entendimento do uso e ocupação territorial da micro-bacia do Rio Samambaia.

Um dado inicial interessante que das cento e treze propriedades estudadas pela autora (parceladas e não parceladas), apenas treze desempenham atividades agrícolas, enquanto cem exercem outras atividades. Especificando o resultado, entre as ocupações, vinte por cento correspondem a comerciantes, vinte por cento a funcionários públicos, onze por cento a agricultores, nove por cento a empresários, oito por cento a comerciários, quatro por cento a donas de casa, e nove por cento a profissões urbanas diversas como: auxiliar de enfermagem, bancário, advogado, representante comercial, zelador, motorista, entre outros. Esta composição comprova a descaracterização da área segundo sua finalidade original já que a atividade agrícola, com onze por cento de representatividade, está circundada por atividades tipicamente urbanas, correspondente a 89 por cento do restante da localidade. (MACIEL, 2001)

Quanto ao nível de renda da população na localidade, está compatível com o da classe média do Distrito Federal. Isto pode ser comprovado pela amostragem que demonstra que quarenta e seis famílias têm rendimento acima de dez salários mínimos e vinte famílias, entre seis a dez salários, o que resulta em um total de cinqüenta e nove por cento da amostra. No item escolaridade há um diferencial de perfil que aponta para a significativa mudança nos anos de estudo, predominando na localidade uma população de maior nível educacional. Enquanto os chacareiros remanescentes obtiveram o percentual de dezessete por cento no somatório de ensino nível superior, a população que mora em chácaras parceladas atingiu sessenta e seis por cento. (MACIEL, 2001)

Sobre a origem das pessoas entrevistadas, houve o predomínio Centro-Oeste com quarenta por cento dos entrevistados da amostra, seguidos na proporção de vinte e sete por cento para a região Sudeste, vinte e cinco por cento para a região Nordeste, cinco por cento para a região por cento para a região Norte. (MACIEL, 2001)

Confirmando o forte processo de transformação territorial que atua na microbacia torna-se interessante a informação obtida pela autora que cinqüenta e nove por cento dos chacareiros remanescente entrevistados receberam entre os anos dois mil e dois mil e um, a proposta de compra de imobiliárias, o que demonstra o constante assédio por parte de empresas, indicando um iminente risco de adesão ao parcelamento. (MACIEL, 2001)

No que se refere às razões em mudar-se para a localidade, sessenta e sete por cento da amostra, o fez por questões relacionadas à facilidade de acesso a moradia, 
conjugado ao aspecto de tranqüilidade e maior espaço. Completando os percentuais, vinte e quatro por cento mudaram-se por motivo de emprego e a atividade agrícola contribuiu com apenas nove por cento, como motivador para residir na localidade. Essas informações baseiam-se no processo gradual de mobilidade da classe média residente no Plano Piloto e em regiões administrativas, como Guará e Taguatinga, para outras áreas residenciais no Distrito Federal, configurando a reprodução de um modelo de habitabilidade nos termos de um referencial de classe que leve em consideração aspectos como:

- tamanho de lotes;

- localização;

- estilo de casa;

- projeto de arquitetura;

- segurança do local.

Todos esses critérios de escolha são elementos simbólicos preconizam a eficácia desse espaço como um modelo ou um estilo de vida, onde se busca realizar um ideal de moradia de melhor qualidade e ainda desfrutar da proximidade do centro da capital do país. (MACIEL, 2001)

Em contrapartida, embora os fatores tranqüilidade e maior espaço fossem mencionados como umas das razões de se mudarem para a região do Rio Samambaia, o item tranqüilidade encontra-se em oposição ao fator segurança, que foi amplamente citado entre as carências na localidade. Dessa forma, observa-se que com o passar do tempo, consolida-se um novo bairro, de poder aquisitivo atraente, e surgindo os demais problemas comuns as outras Regiões Administrativas do Distrito Federal. (MACIEL, 2001)

Analisando a questão do ano em que houve a mudança para a localidade, as informações obtidas pela autora mostram que o processo foi mais acentuado entre mil novecentos e noventa e um a dois mil, quando sessenta e seis por cento das mudanças ocorreram. Estes dados são corroborados por dados obtidos no monitoramento multitemporal desenvolvido no presente trabalho, que mostram a evolução espacial. Essa época compreende ao período de maior expansão dos denominados condomínios, quando mais de 80 mil lotes foram distribuídos, ocupado ou vendido, sendo quase todos em assentamentos. (MACIEL, 2001)

Esse processo intensificou-se com a aprovação do PDOT/97 e PDL de Taguatinga que legitimou as áreas ocupadas, alterando o macro-zoneamento definido no PDOT/92. Desta forma, permitiu a ocupação com usos diversificados e introduziu o conceito de flexibilização de uso.

Com relação aos chacareiros remanescentes entrevistados, que são quinze por cento da amostra trabalhada pela autora, apontou-se que oitenta e oito por cento deles ainda conservam as chácaras em sua forma original, sem parcelamento. Vale ressaltar que cinqüenta e nove por cento deles receberam proposta de venda entre 2000 e 2001, época de desenvolvimento da pesquisa, sendo cinqüenta e cinco dessas propostas de imobiliárias. (MACIEL, 2001)

Percebe-se o processo de mudança que a autora mostra, já que das chácaras remanescentes existentes apenas onze por cento querem aumentar a produção, 
apesar de cinqüenta e oito por cento deles não terem problemas de comercialização e cinqüenta e três por cento acharem que os investimentos compensam. Tais dados comprovam que a atividade agrícola vem cedendo espaço e dando lugar aos parcelamentos e à expansão urbana desordenada. (MACIEL, 2001)

Analisando a questão da água, observou-se que não existe uma preocupação dos moradores com a disponibilidade dos mananciais de abastecimento, seja superficial, seja subterrâneo; aos chacareiros remanescentes, apenas seis por cento se abastecem da água do Rio para irrigar a produção. Do total entrevistado, noventa e quatro por cento têm como fonte de abastecimento o poço artesiano para o consumo domiciliar, embora sessenta e seis por cento achem que a essa água é não apropriada para o consumo. (MACIEL, 2001)

\subsection{Um Eixo de Expansão}

Diante do que foi apresentado, percebe-se que o eixo de ligação entre Taguatinga, Ceilândia e Plano Piloto é sem dúvida um eixo de crescimento urbano, por se tratarem dos maiores pólos de atração do Distrito Federal. A abertura de vias como a EPCL (Estrada Parque Ceilândia), a conhecida Via Estrutural ou ainda a DF-095 com seus 12,6 km de extensão; é a divisa norte da micro-bacia do Rio Samambaia; a EPVL (Estrada Parque Vale ou DF-087) que liga a Estrutural à EPTG passando pelo Jóquei e a EPVP (Estrada Parque Vicente Pires ou DF-079), que liga a EPTG à Estrada Parque Núcleo Bandeirante, contribuíram ainda mais para a ocupação dessa localidade, cuja vocação original era a atividade rural.

O fato é que esse crescimento/expansão estrutura-se por um meio termo, onde se muda a paisagem de rural para urbano, mas não totalmente. Zona urbana é a área caracterizada pela edificação contínua e a existência de equipamentos sociais destinados ás funções urbanas básicas, como habitação, trabalho, recreação e circulação.

Seguindo-se essa linha de pensamento, a região da micro-bacia do Rio Samambaia não se caracteriza por plenamente urbana, devido à carência de infraestrutura e de equipamentos urbanos adequados à ocupação humana, gerando consigo vários problemas sócio-ambientais. Tem ainda a questão fundiária, já que os moradores daquela região não são donos das terras, pois as mesmas pertencem à União e ao GDF, sendo que nem mesmo o governo sabe qual parte pertence a quem. Todo esse clima de incerteza, gera muita ansiedade por parte dos moradores e inúmeros conflitos. As ocupações de áreas de maior vulnerabilidade ambiental são passíveis de operações de erradicação, fomentando a animosidade entre os moradores e o Estado.

A região da micro-bacia do Rio Samambaia, mesmo sendo considerada como área rural remanescente, é hoje uma área de expansão urbana, carecendo que seus loteamentos sejam aprovados pelos órgãos competentes, destinados à habitação, à indústria ou ao comércio, mesmo que localizados fora das zonas definidas nesses termos, já que a ocupação está feita e a retirada de todas essas pessoas na região estimularia um verdadeiro clima de guerra na região.

Um planejamento urbano estruturado em setorização funcional das atividades que eram acompanhadas de regras restritivas de uso e ocupação do solo junto com a 
adoção de soluções pontuais para solucionar os problemas de longa data, gerou impasses na ação governamental que, - num quadro de demandas habitacionais, por parte de determinados segmentos sociais não atendidos, - acabaram por estimular a irregularidade da ocupação.

\subsection{Intervenções Identificadas na Micro-bacia do Rio Samambaia}

É importante ressaltar que a proposta é identificar intervenções na micro-bacia e não ser um estudo de impacto ambiental, que é algo mais amplo e complexo. A definição e caracterização das intervenções são importantes, pois sua análise poderá direcionar a distribuição de novas construções do empreendimento, inclusive propondo alternativas que minimizem ou eliminem os impactos individuais e sua associação. A seguir estão listadas intervenções na micro-bacia relativas ao meio sócioambiental, que são atribuídos ao tipo de ocupação a que este estudo se refere:

\section{A Micro-bacia do Rio Samambaia como Palco de um Conflito Sócio- Ambiental}

É incontestável que hoje, a micro-bacia do Rio Samambaia é uma região de litígio, onde os diversos atores envolvidos estão em constante embate, na manutenção de seus interesses. As ações do governo do Distrito Federal ainda são tímidas, diante da problemática e pelo que se percebe, será novamente efetuada a política da regularização do irreversível, ratificando o modelo de gestão do território em voga no Distrito Federal.

O cerne do quadro conflituoso se desenvolveu nos processos de parcelamento das glebas e na subseqüente ocupação, que é contínuo e deve perdurar até a ocupação total da área. O conflito é motivado por interesses difusos de diferentes atores sociais, de tal sorte que identificá-los passa a ser uma premissa básica para entender os seus comportamentos e a sua disposição para elaboração de uma proposta resolutiva.

Em linhas gerais a análise do conflito sócio-ambiental segue a seguinte estrutura.

Analisando-se essa matriz podem ser destacados alguns pontos importantes na identificação desse atores. Os moradores podem ser divididos em categorias, que seriam os:

1) Arrendatários: Atores importantes no processo de parcelamento, motivados pelo aspecto financeiro, procuraram garantir antecipadamente a indenização sobre as benfeitorias realizadas em sua gleba. São pessoas físicas que receberam do GDF, a concessão para uso da terra, para fins de produção agrícola, pôr prazos de trinta a cinqüenta anos. Estes não tinham a escritura definitiva da terra, que ainda pertence ao governo distrital. No caso de desapropriação, os arrendatários receberiam indenização pelas benfeitorias realizadas na chácara. Entretanto, havia a possibilidade de transferência deste direito de posse a terceiros, os quais assumiriam as mesmas responsabilidades, junto ao GDF. Vale ressaltar que os arrendatários não tinham o direito de fracionar as glebas nem de transformá-las em condomínio. No entanto vários arrendatários cedem às pressões dos especuladores e autorizam o parcelamento de suas glebas em lotes menores. 
2) Compradores: Dividem-se entre os de interesse econômico e social. Alguns procuraram no parcelamento da micro-bacia a garantia do direito à moradia e também há os que atuaram na vertente da especulação imobiliária. São pessoas físicas, em sua grande maioria de classe média, que vislumbraram no parcelamento irregular das colônias agrícolas Samambaia, Vicente Pires e Vila São José Águas Claras a possibilidade de resolver a sua demanda por conforto habitacional. Os compradores podem ser classificados em quatro grupos distintos:

a) Moradores de aluguel - A falta de moradias e de programas governamentais para atender a demanda da população força o indivíduo a buscar autonomia habitacional;

b) Moradores em imóveis próprios - Procuraram um meio para atender a demanda por conforto. Vêem nos lotes a possibilidade de construir casas mais confortáveis;

c) Moradores em imóveis próprios financiados - A política atual do Sistema Financeiro Habitacional vem provocando um alto índice de inadimplência por parte dos mutuários que não conseguem honrar os contratos assinados. Os parcelamentos irregulares são opção para equilibrar o orçamento familiar.

d) Especuladores imobiliários - Aproveitam a articulação do mercado informal, com a finalidade de obter ganhos futuros. Também constróem prédios e casas para alugarem.

3) Grileiros: Estes possuem um interesse totalmente financeiro, rompendo com todos os limites legais para implantar condomínios. Geralmente desaparecem deixando a cargo dos compradores toda a responsabilidade pelas infrações cometidas. São agentes de grande força no processo de transformação territorial, principalmente em sua fase inicial. Sua estratégia é exercer forte pressão sobre os arrendatários, comprando glebas, parcelando-as, comercializando-as e sumindo de cena.

4) Os políticos oscilam entre a preocupação social e o interesse pessoal de projeção visando as eleições, já que ocorreram propostas e promessas que geralmente após o pleito eleitoral não são cumpridas. O envolvimento de parlamentares nas questões fundiárias é uma realidade, principalmente no que diz respeito à regularização.

O assuntou virou moeda eleitoral durante a campanha eleitoral de 2002. Vários candidatos fizeram promessas de legalização dos parcelamentos, inclusive os candidatos ao governo do estado. A promessa de regularização e implantação de infraestrutura estimulou ainda mais a procura por lotes e a proliferação dos condomínios. Muitos políticos têm se mostrado interessados em resolver o problema, talvez pensando no quantitativo de famílias envolvidas. No dia 21 de maio de 2003 a Comissão de Assuntos Fundiários - CAF da Câmara Legislativa aprovou projeto de lei que prevê a venda direta de terrenos em loteamentos irregulares aos ocupantes. Isto é mais um indicativo do envolvimento político na questão.

5) O ministério público que atua não só nessa micro-bacia, mas também em todo o DF na tentativa de coibir o parcelamento irregular e punir os responsáveis evocando o princípio da legalidade jurídica para a regularização fundiária e na defesa ambiental. Sua ação esbarra em constantes liminares a favor dos ocupantes de edificações em áreas de preservação permanente, mesmo com a vigência do código florestal. O MPDFT defende a licitação como o meio de regulação dos condomínios.

Revista Eletrônica: Tempo - Técnica - Território, V.3, N.1 (2012), 86:124 ISSN: 2177-4366 
Entretanto é considerável a quantidade de situações claramente contrárias ao meio ambiente e aos interesses coletivos nessas localidades o que trava os processos de licitação. O Ministério Público vem apurando questões de grilagem no Distrito Federal e procedendo a investigação de várias denúncias.

6) Quanto ao governo do Distrito Federal, a atuação desse ator pode ser analisada sob diferentes óticas. Uma delas seria a social. Chegará o momento em que o GDF terá que agir de forma efetiva com relação às ocupações irregulares, já que milhares de famílias residem nesses lotes e espera do governo um posicionamento com relação à legalização fundiária. Outra seria o econômico pois essa situação de irregularidade causa prejuízos ao erário público, já que o governo não recebe pela venda da terra e também não arrecada nada com impostos como o IPTU. O político já que o jogo de omissão e promessas de regularização fundiária pode ser utilizado como instrumentos de manejo político em períodos eleitorais. Os órgãos diretamente envolvidos são: a Secretaria de Meio Ambiente - SEDUMA - a Secretaria de Segurança Pública, através da SUDESA, a CAESB, a CEB com a infra-estrutura e a TERRACAP, responsável pela gestão das terras públicas pertencentes ao GDF. A TERRACAP defende e vem aplicando o processo de licitação para regularizar os condomínios irregulares. O governador apóia a postura da empresa, todavia vem dando sinais de que poderá alterar o modelo, caso encontre respaldo legal. O Governo do Distrito Federal não conseguiu inibir a proliferação dos parcelamentos e atualmente não consegue estabelecer um modelo que viabilize o controle e a fiscalização das terras públicas.

7) $O$ governo federal através do IBAMA e da SPU. O primeiro tem o foco na proteção ambiental das áreas de preservação permanente. O licenciamento ambiental que é concedido por esse órgão e as obras de infra-estrutura só poderá ser iniciado com a erradicação das edificações em áreas de preservação permanente, o estopim do conflito. Percebe-se também que a posição política distinta do governo distrital e federal utiliza a questão das erradicações como ferramenta para disputas políticopartidárias. A SPU tem interesse principalmente na questão social e fundiária, já que está vinculado ao ministério das cidades, que tem projetos de legalização fundiária de ocupações urbanas em todo o país. Parte das terras ocupadas na micro-bacia pertence à União. A SPU se colocou favorável a regularização e apresentou uma proposta de legalização, mas vem desagradando integrantes de outras partes do governo federal, como também a Casa Civil da Presidência da República. Entende-se que tais restrições sejam de caráter político, uma vez que a polarização no Distrito Federal está muito acirrada.

\subsection{Histórico do Conflito}

Por tratar-se de uma ocupação urbana consolidada e que não passou pelas etapas do licenciamento ambiental nem de plano urbanístico, cabe ressaltar que os ocupantes da micro-bacia estão fazendo o processo inverso para conseguir a regularização de sua área. Atualmente se realiza as etapas que seriam anteriores a compra dos terrenos: licenciamento ambiental, licença de instalação (aprovação do projeto urbanístico) e licença de operação. Para tanto se demandou a encomenda de um Estudo e Relatório de Impacto Ambiental - ElA/Rima que fez um diagnóstico da ocupação, apontando os danos e as ameaças ao meio ambiente. O documento 
também define os limites de expansão residencial da área e recomenda medidas de compensação ambiental e está sob avaliação do IBAMA e SEDUMA, podendo aprová-lo por completo, aprovar com condicionantes ou condenar o setor habitacional.

O mais aceitável é que seja aprovado, ou aprovado com ressalvas, e a comunidade, baseada nesse parecer faz um plano de ajuste da ocupação, comprovando que os danos serão sanados. Esse plano é submetido ao processo de obtenção das três licenças: licença ambiental prévia, licença de instalação e licença de operação. Nesse caso, a infra-estrutura urbana não seria construída, mas adaptada.

Diante do desafio da regularização fundiária dessa localidade, várias iniciativas foram tomadas. Em junho de 2005, IBAMA, GDF, moradores e Secretaria de Patrimônio da União - SPU, vinculada ao Ministério do Planejamento, firmaram convênio objetivando a regularização. O maior entrave a esse processo a proibição de novas construções. Outro Grupo de Trabalho - GT se constituiu para regularizar as áreas rurais, ocupadas com precários contratos de arrendamento. Essas terras seriam vendidas via licitação pública pela TERRACAP. Entretanto a Empresa de Assistência Técnica e Extensão Rural do DF - EMATER protestou da decisão alegando que o impacto gerado pela licitação de lotes rurais irregulares no DF seria imensurável, o que deflagrou uma onda de insegurança e questionamentos judiciais. (CARVALHO JÚNIOR, 2007)

Buscando contornar a situação, em setembro de 2005, o então governador do DF Joaquim Roriz mediante decreto que permitiu a licitação de lotes em área rurais onde a situação fundiária não esteja sob júdice e que possuíssem planejamento territorial (casos extremamente raros). Tal medida também gerou a insegurança entre os proprietários rurais, já que muitos alegavam, a época, a possibilidade de perder o terreno para terceiros, uma vez que a licitação prioriza o comprador que oferecer o maior montante financeiro pelo terreno. Na mesma época, a Comissão de Constituição e Justiça do Senado Federal aprovavam um projeto de lei que permitia a cessão dos terrenos que pertencessem em áreas da União, caso da Colônia Agrícola Vicente Pires, mas ficando de fora Colônia Agrícola Samambaia e Vila São José, que estão em áreas do GDF.

Nessa tentativa de regularização, a avaliação do terreno seria calculada sem as benfeitorias; a venda poderia ser parcelada, com o pagamento de um sinal de $10 \%$ e o restante dividido em até 120 meses; após a compra, o morador fica proibido de vender o imóvel por 05 anos; os recursos obtidos pela venda direta seriam destinados à construção de moradias populares; o ocupante só poderia comprar um único lote; e, por fim, o morador deverá comprovar efetiva ocupação do terreno há, pelo menos, 05 anos da data de publicação da lei. Vale ressaltar que, do ponto de vista prático nada aconteceu até o presente momento. (CARVALHO JÚNIOR, 2007)

Também em setembro de 2005 foi firmado um Termo de Ajustamento de Conduta - TAC com vistas à liberação do licenciamento ambiental para implantação das redes de água e esgoto na área que engloba as Colônias Agrícolas Samambaia, Vicente Pires, e Vila São José, pertencentes à mesma região geográfica . De acordo com o TAC, dois promotores do Ministério Público Federal - MPF fiscalizariam o cumprimento do acordo, assinado entre o IBAMA, CAESB, Agência Reguladora de Água e Saneamento - ADASA, Secretaria de Coordenação das Administrações Regionais - 
SUCAR, Secretaria de Meio Ambiente e Recursos Hídricos - SEMARH, Sistema Integrado de Vigilância, Preservação e Conservação de Mananciais - SIVÁGUA, além da Secretaria de Segurança Pública - SSP.

Ao SIV-ÁGUA caberia a tarefa de levantar as Áreas de Preservação Permanente - APP da região e apresentar um relatório sobre os limites das mesmas, além das edificações e construções da área. A CAESB se encarregaria de demarcar as áreas de APP apontadas pelo SIV-ÁGUA. A SEMARH fiscalizaria essas etapas, elaborando relatórios que seriam entregues ao IBAMA periodicamente.

Após essa etapa, o SIV-ÁGUA coordenaria operações de erradicação de edificações erguidas nas APP no prazo de, no máximo, um ano após a assinatura do TAC, sendo essa demolição uma das exigências para emissão da licença de instalação para o setor. Todas as entidades deveriam impedir, continuamente, novas invasões e construções. Ainda segundo o TAC, após as demolições, haveria um reflorestamento da área com o plantio de mudas. Em abril de 2006, o SIV-ÁGUA finalizou a demarcação das construções/ocupações que estavam em APP, além do levantamento de todas as construções que deveriam ser demolidas. Em julho de 2006, o IBAMA iniciou as notificações para os moradores dessas residências/construções edificadas ilegalmente em APP à abandonarem os imóveis.

Em julho de 2006, a Procuradoria Geral do Distrito Federal - PGR recomendou ao IBAMA a suspensão do TAC, alegando que o GDF não cumpriria as atividades, nem tampouco o calendário acordado no TAC. O IBAMA então deu prazo de cinco dias para que o GDF apresentasse novo cronograma de derrubadas para as construções em APP, caso contrário, suspenderia a licença para instalação da rede de água. Até o final do mês de julho de 2006, apenas 12 edificações tinham sido efetivamente derrubadas.

Argumentando que realmente não conseguiria cumprir as metas estabelecidas no TAC, o SIV-ÁGUA solicitou um prazo maior para efetivar as derrubadas de construções/ocupações em APP. Entretanto, o prazo de cinco dias, estipulado pelo IBAMA expirou e as obras de construção de água e esgotos na Colônia Agrícola Vicente Pires foram suspensas, tendo em vista que o GDF não cumpriu com atividades e prazos firmados no TAC. Apesar da suspensão e, sem nenhuma resposta do IBAMA, em setembro de 2006, o GDF elaborou novo cronograma de derrubadas, mês em que o TAC efetivamente venceria e as obras da CAESB nas Colônias Agrícolas Vicente Pires, Samambaia e Vila São José.

Vários foram os fatores que influenciaram a lentidão do processo de operações de erradicação de edificações, necessária para o licenciamento ambiental das obras. As inúmeras liminares concedidas aos moradores, proibindo às ações de derrubadas de casas localizadas em APP, o intenso período de chuvas, e a péssima gestão, humana e administrativa, por parte do GDF em cumprir o TAC, além do traumático e difícil processo de erradicação de edificações habitadas. Realmente a estrutura estatal falhou em deixar as coisas acontecerem à revelia na ocupação territorial da microbacia do rio Samambaia. O ideal teria ser evitado, mas depois de estruturado, a remoção dessas famílias é extremamente difícil. Muito se critica órgãos como o extinto Siv-Água ou atualmente a SUDESA, entretanto só quem viveu o cotidiano de lidar olho no olho com moradores entende o que é estar nesse ingrato ofício e compreende o real significado e conseqüências da omissão estatal.

Revista Eletrônica: Tempo - Técnica - Território, V.3, N.1 (2012), 86:124 ISSN: 2177-4366 
A discussão acerca da modalidade de venda dos lotes é fonte de imensuráveis discussões. Moradores alegavam que a licitação promoveria a especulação e que eles, ao comprarem os lotes, agiram de boa-fé tendo, portanto, o direito de preferência na compra. Por outro lado, TERRACAP afirma ser a proprietária das terras e, sendo estatal, seus bens só podem ser vendidos na forma de licitação, de acordo com a lei 8.666/93 - Lei de Licitações e Contratos. Em janeiro de 2006, uma comissão criada pelo GDF, constituída por representantes da TERRACAP, Companhia de Saneamento Ambiental - CAESB, Companhia Energética de Brasília - CEB, Secretaria de Desenvolvimento Urbano e Habitação - SEDUH, Procuradoria Geral do DF - PGR, além de 05 integrantes do Movimento Morar Legal, se reuniram na tentativa de encaminhar soluções para a regularização fundiária através da lei de licitações e contratos. O maior destaque para a questão, é único ponto de consenso da comissão foi que, para os condomínios irregulares, poderia ser aplicada a Lei 8.025/90, uma vez que, em seu artigo 60 há uma exceção. Tal exceção consiste em conceder aos atuais ocupantes 0 direito de preferência antes da publicação de um edital de concorrência. Há ainda o período de 30 dias para os atuais ocupantes manifestarem interesse ou não em adquirir o bem. $\mathrm{O}$ argumento mais forte, porém, baseou-se na alegação de que esse modelo foi o utilizado na década de 90 na venda dos imóveis funcionais da União. Para que tal exceção também pudesse ser aplicada no Distrito Federal, o Executivo local teria que apresenta um projeto de lei aplicando a regra às terras do Distrito Federal, o que não aconteceu, dada a ampla polêmica acerca do modelo de venda dos lotes. (CARVALHO JÚNIOR, 2007)

Ainda em janeiro de 2006, o TJDFT, atendendo a uma solicitação, através de um mandado de segurança do MP, suspendeu as políticas habitacionais do DF. Segundo o MP, as políticas habitacionais no DF são compostas por decretos expedidos pelo governador, o que contraria a Constituição. Ainda segundo o MP, as políticas públicas habitacionais devem ser reguladas por lei, discutidas e aprovadas pela CLDF. Obviamente, após a suspensão, várias ações judiciais, inclusive liminares das mais variadas, surgiram seqüencialmente. Em março de 2006, o Ministério Público buscou garantir na justiça que a regularização dos condomínios irregulares do Distrito Federal fosse feitas por meio da licitação pública já que segundo o MP as leis que respaldam a venda direta são inconstitucionais e que os dispositivos soberanos são os que prevêem a concorrência. Em março de 2006, a União, por intermédio da SPU, se baseou no tempo de moradia do atual ocupante da terra, além de seguir as normatizações da Lei 9.636/98 que rege o patrimônio da União, para estruturar um modelo para regularização de suas terras no Distrito Federal. Teriam direito de preferência os ocupantes que comprovarem moradia efetiva antes de fevereiro de 1996. Para os ocupantes de fevereiro de 1996 ao fim de 1997, o critério será o da concorrência pública, mas o morador, ao igualar a proposta financeira, poderia ficar com o lote. Os outros casos, de moradores que ocuparam a área após 1997, não haveria outro meio a não ser através da licitação.

Entretanto o Ministério Público, solicitou ao Procurador Geral da República que ajuizasse uma Ação Direta de Inconstitucionalidade - ADIN contra o modelo. A alegação para o ajuizamento da ação foi a de que a Lei $9.636 / 98$ não poderia ser aplicada, uma vez que dar o direito de preferência, a quaisquer que seja, na compra de 
um bem público contraria a Constituição Federal e a Lei de Licitações e Contratos, já citadas. (CARVALHO JÚNIOR, 2007)

Acerca do licenciamento ambiental, a proposta da nova lei seria de existir um único documento, ou seja, uma licença integrada, além de liberar parcelamentos pequenos, de até 100 hectares, do licenciamento ambiental como é feito atualmente.

Em abril de 2006, o Governo Federal editou Medida Provisória, n 292 - chamada de MP Fundiária - que permitiria a cessão de uso e ocupação do solo em áreas da União. Entretanto, seu prazo para ser votada pelo Congresso Nacional expirou e a referida MP não saiu do papel, não resultando, portanto, qualquer efeito para as ocupações irregulares no Brasil e no DF. (CARVALHO JÚNIOR, 2007)

Os produtores rurais, que efetivamente produzem frutas e hortaliças, não só os da Colônia Agrícola Vicente Pires, se reuniram em maio de $2006 \mathrm{com}$ a comissão gestora que está executando a revisão do PDOT. Na reunião, os produtores rurais posicionaram-se contrários a decisão do GDF de transformar as áreas rurais remanescentes em área urbanas, como constava na revisão do PDOT, iniciada por ação do MP e executada pela SEDUH. A SEDUH se posicionou favorável à reivindicação, sinalizando que as propriedades rurais que tenham mais de 02 hectares vão continuar com características rurais, mesmo que estejam localizadas em áreas urbanas, caso da micro-bacia do Rio Samambaia. Ainda segundo a SEDUH, os proprietários obterão o título de uso por mais 30 anos, desde que não parcele ou repasse essa cessã o para terceiros. Somente no início de junho de 2006, depois de mais de 01 ano após ter firmado convênio com o IBAMA e moradores, a SPU reiniciou as atividades previstas para a regularização da área da micro-bacia do Rio Samambaia. A primeira etapa seria de cadastrar os atuais ocupantes das "chácaras" da Colônia Agrícola Vicente Pires. Ao todo, o processo compreenderá:

- Cadastramento dos imóveis, com a colaboração do Exército;

- Elaboração de EIA/RIMA, custeado pelos moradores;

- Aprovação de projeto urbanístico, também custeado pelos moradores, mas avaliado e aprovado pela SEDUH;

- Avaliação dos terrenos, pela Caixa Econômica Federal - CEF; e

- Venda.

A SEMARH também iniciou a tentativa de regularizar áreas ocupadas irregularmente em terras do GDF seguindo, basicamente, os procedimentos da SPU acima citados e, concomitantemente, uma varredura nos processos de solicitação para emissão de licenças ambientais para os condomínios irregulares. Nesse processo iniciou-se a discussão sobre a dispensa de licença prévia para condomínios já construídos e consolidados como medida de flexibilização e celeridade para a questão fundiária dos loteamentos irregulares em áreas do GDF. Entretanto, a dificuldade principal desse processo foi delimitar que órgãos legislam sobre quais áreas, se IBAMA ou SEMARH, tendo em vista o DF poder ser considerado um mosaico de áreas protegidas. Em agosto de 2006, surgiu a proposta de agrupar condomínios como setores habitacionais concretizada via portaria. A proposta reduziria, portanto, etapas do licenciamento ambiental, determinando que os loteamentos não sejam analisados individualmente, ou seja, agrupam-se condomínios, considerando o setor habitacional que eles formam juntos. Segundo a Portaria, haverá uma elaboração do plano de 
ocupação e TR para o estudo ambiental da área a ser licenciada. Em seguida, executarão os estudos urbanísticos e ambientais. Tais estudos serão analisados pelo CONAM.

Sendo aprovados, ocorrerá a assinatura do Termo de Compromisso para realização das obras de infra-estrutura e medidas para redução dos danos ambientais. Cumprindo esse termo, emissão do licenciamento ambiental e aprovação do plano urbanístico. Por fim, registro cartorial da regularização e implantação das obras pertinentes. Apesar de estar em consonância com a legislação vigente e objetivando facilitar a execução de estudos urbanísticos e ambientais, tal portaria não tem força de lei. Deverá ser apresentada aos moradores, para emissão de sugestões e, somente após a concordância de ambas as partes, deverá ser assinada pelos titulares da SEDUH e SEMARH. Trata-se de uma proposta extremamente factível, entretanto, com a extinção da SEMARH, no início de 2007, o modelo está parado em seus trâmites administrativos e sem previsão de retomada nas negociações. (CARVALHO JÚNIOR, 2007)

Diante desse sinuoso cenário fundiário do DF, houve a aprovação de projeto de lei que estendeu a validade das licenças ambientais emitidas pelos órgãos competentes. No projeto de lei, as licenças prévia, de instalação e de operação passam a valer por cinco, seis e dez anos, respectivamente. Antes, o prazo para cumprir as exigências de todas essas licenças era de um ano. Com o objetivo de avançar e desburocratizar os processos de regularização, o GDF publicou Portaria, em setembro de 2006, que permite aos ocupantes de parcelamentos irregulares dar início aos estudos urbanísticos enquanto os processos ambientais são analisados pelo órgão competente, IBAMA, em áreas da União e SEMARH, em áreas do GDF.

Em dezembro de 2006, SIV-ÁGUA e a empresa que está elaborando o EIA/RIMA da Colônia Agrícola Vicente Pires anunciaram que, em conjunto, farão um novo estudo para delimitar áreas que estão em APP, uma vez que o primeiro estudo do SIV-ÁGUA apontou cerca de 549 construções em APP. A intenção do novo estudo seria delimitar, precisamente, casas construídas a menos de 30 metros de corpos d'água e 50 metro de nascentes, conforme prevê a legislação ambiental.

\subsection{Como o Conflito se Estrutura}

Percebeu-se no desenvolvimento da pesquisa que para um efetivo entendimento do uso e ocupação territorial da micro-bacia do Rio Samambaia e seus conflitos seria necessário um enfoque crítico da "questão sócio-ambiental" os conflitos são estruturalmente postos em um palco - a micro-bacia - no qual ser opõem diferentes grupos sociais - atores - em condições assimétricas de poder e lutando pela atribuição de distintos significados e usos territoriais.

Esse processo de clivagens social faz com que a delimitação do objeto de conflito se desloque de uma ótica "biologista" como, por exemplo, uso dos recursos hídricos da micro-bacia ou a integridade da áreas de preservação permanente, para um ponto de vista "sociológico". O que ocorre nessa micro-bacia hidrográfica, transcende a manutenção da sustentabilidade de um rio para uma expressão de lutas sociais originadas quando os atores percebem ameaças nas formas sociais de apropriação do meio em que vivem por intervenções indesejáveis (vistas de uma maneira lato) decorrentes do exercício das práticas de outros grupos. Isso coloca em

Revista Eletrônica: Tempo - Técnica - Território, V.3, N.1 (2012), 86:124 ISSN: 2177-4366 
pauta conflitos "sócio-ambientais" pela apropriação de elementos constitutivos da base reprodução de grupos sociais. (CARNEIRO \& BARROS, 2006)

Essa visão contribui para uma abordagem geográfica do conflito, abordado sobre a égide do conceito de "território", que inclui as práticas e conflitos sociais de apropriação material e simbólica de condições naturais particulares. E na conjuntura de uma sociedade capitalista percebe-se uma distribuição desigual das possibilidades de acesso, controle e uso dos diferentes territórios, assim como as lutas sociais em torno dessa distribuição. Esse modelo de "desigualdade territorial" se expressa no ambiente urbano, na distribuição espacial da população, onde camadas mais pobres são "empurradas" para áreas em que se concentram os efeitos problemáticos oriundos da ação de grupos sociais dominantes, tais como inundações, afundamentos, desabamentos, carência de equipamentos de saneamento básico, coleta e tratamento de lixo e esgoto. (CARNEIRO \& BARROS, 2006)

Trabalha-se, portanto, na perspectiva do papel dos conflitos sócio-ambientais na construção de territórios urbanos, a partir de um estudo de caso que procurou reconstituir os processos e conflitos que resultam na atual forma de ocupação do território da micro-bacia hidrográfica do Rio Samambaia, no Distrito Federal.

Percebeu-se que a formação do território urbano na micro-bacia do Rio Samambaia (processo de transformação de área rural remanescente para área urbana) habitado por classes populares, resulta da interação da espacialização urbana das desigualdades geradas pela:

a) economia de mercado;

b) por omissões e ações seletivas do Estado;

c) pelas lutas e práticas coletivas organizadas pela população.

Estes se articulando a outros atores, buscam promover formas de apropriação do território e provimento de serviços de infra-estrutura de acordo com seus interesses. Aquilo que as sociedades fazem com seu meio material não se resume a satisfazer carências e superar restrições materiais, mas consiste também em projetar no mundo diferentes significados - construir paisagens, democratizar ou segregar espaços, padronizar ou diversificar territórios sociais. (ACSERALD, 2004).

Pelo que foi dito, por mais que as intervenções claras e explícitas como edificações em áreas de preservação permanente, contaminação dos rios e nascentes, conflitos entre GDF e moradores nas operações de erradicação de edificações, entre outros, descrevam o momento mais direto pelos quais os atores transformam o meio biofisico, é importante compreender que essas intervenções são condicionadas pelas formas sociais e culturais, ou seja, pelas opções da sociedade do Distrito Federal em um modelo e uma cultura de territorial. Dessa forma, as condições de produção do espaço na micro-bacia do Rio Samambaia, são o campo de relações que os grupos entretecem no espaço social, em que se constróem as próprias visões do mundo social e de suas relações com a natureza. Em relação a esse entendimento torna-se necessário enfatizar o tipo de poder entre os distintos participantes do conflito e os antagonismos entre interesses, os símbolos e visões de mundo além das relações sociais, políticas e econômicas entre os atores envolvidos e identificar os impactos ambientais existentes ou potenciais. Essa necessidade decorre do fato de que 
geralmente os conflitos sócio-ambientais eclodem nos territórios e todos os usos e sentidos atribuídos ao meio, interagem e conectam-se materialmente e socialmente seja por meio das águas, do solo ou da atmosfera. (LITTLE, 2001, NASCIMENTO, 2001)

Abordar um conflito sócio-ambiental apoiando-se no conceito de território nos leva à idéia de territorialidade, construída por práticas de apropriação do mundo resultado da relação entre espacialidade geográfica, organização ecológica e significação cultural, que se delineiam por meio de identidades culturais e da forma de apropriação da natureza. Assim a territorialidade pode ser definida como o esforço coletivo de um grupo social para ocupar, usar, controlar e se identificar com urna parcela específica de seu ambiente biofisico, convertendo-a assim em seu "território". É uma força latente em qualquer grupo, cuja manifestação explícita depende de contingências históricas, necessidades e demandas. (LITTLE, 2001)

A territorialidade humana tem uma multiplicidade de expressões, o que produz um leque muito amplo de tipos de territórios, cada um com suas particularidades socioculturais que cada grupo social utiliza para estabelecer e manter seu território, como seu regime de propriedade, a história da sua ocupação guardada na memória coletiva, o uso social que dá ao território e as formas de defesa dele. (LITTLE, 2001, NASCIMENTO, 2001)

Portanto os conceitos de espaço, território e territorialidade demarcam, cada vez mais, a íntima relação entre a questão urbana e a questão ambiental. Portanto, a análise do urbano com um "olhar ambiental" deve estar centrada nas condições de vida adequadas às comunidades, enfatizando suas relações com a diversidade social e do ambiente onde vivem - com seu território; território fruto do esforço coletivo que um grupo social ocupa, usa, controla a partir de seu ambiente biofisico - como construção de sua territorialidade. (MONTE-MOR, 1997).

Diante do que foi até agora exposto é possível perceber que as transformações na compreensão do processo de uso, apropriação e organização econômica do território colocam o espaço urbano como resultado de profundas transformações antrópicas sobre o meio físico ao longo dos tempos, dos quais o caso da micro-bacia do Rio Samambaia, é mais um no Distrito Federal. É o processo histórico de ocupação do território, como as suas transformações, em uma determinada época ou sociedade que faz com que o meio ambiente tenha um caráter dinâmico, pois o espaço é movimento. (SANTOS, 2005)

Para um entendimento mais lúcido sobre os conflitos sócio-ambientais na microbacia do Rio Samambaia, é importante considerar que meio ambiente (microbacia ou suporte físico) é, também, social e historicamente construído, condicionado e condicionante do movimento transformador da vida social. Portanto, no estudo dos conflitos ambientais urbanos não é possível separar a sociedade e seu ambiente físico, já que as duas dimensões constituem um mundo material socializado e dotado de significados. No entanto, devido a falsa dicotomia entre o ambiental e o urbano era-se uma certa incompatibilidade entre planejamento urbano e planejamento ambiental, a ponto de o setor de desenvolvimento urbano (desenvolvimento do habitat construído) e o de políticas ambientais (políticas relacionadas aos recursos naturais) exercerem comando, por vezes, conflitante no interior do próprio aparelho de Estado brasileiro, resultando em políticas desarticuladas e ineficientes (COELHO, 2005).

Revista Eletrônica: Tempo - Técnica - Território, V.3, N.1 (2012), 86:124 ISSN: 2177-4366 
Exemplificando-se, é perceptível que nas áreas urbanas habitadas por setores mais privilegiados no Distrito Federal, a ocupação do território tende a obedecer a padrões previamente definidos e o provimento de serviços básicos de infra-estrutura urbana é realizado, sob a forma de efetivação de direitos pelo Estado, mais prontamente e de forma integral. Pelo contrário, nas regiões em que vivem as classes subalternas o processo de ocupação tende a ser errático, dependente da mobilização da população e do apoio de outros atores, como exemplo típico os condomínios que se espalham por todo DF. Na micro-bacia do Rio Samambaia, a trajetória de formação do território e de obtenção de serviços de infra-estrutura revela-se uma sucessão conflitos, insucessos e conquistas, muitas vezes parciais e sujeitas a retrocessos. Nesse sentido, a elaboração de modelos de análise dos padrões de construção de territórios urbanos de classes populares deve considerar não apenas o papel do Estado e dos determinantes da economia de mercado, mas também, como inerente a tais padrões, as próprias práticas e lutas de apropriação territorial encetadas pelos habitantes desses territórios.

Isso é bem perceptível nas adjacências da micro-bacia em estudo, porque cruzado pela via Estrada Parque Taguatinga, têm-se de um lado o bairro de Águas Claras que em tese é um setor planejando, com edificações para o público de classe média alta e do outro o chamado setor habitacional Vicente Pires, que está contido na micro-bacia hidrográfica do Rio Samambaia. Apenas por uma estrada, percebe-se o muro invisível e tácito da desigualdade social. De um lado um bairro em efervescência, como serviços públicos como metrô, centros comerciais e universidade e do outro lado, um bairro que se constituiu a revelia do Estado, carente de infra-estrutura básica mínima.

As matrizes desse conflito são realmente distintas, há uma disputa de forças e poderes. Existe de um lado uma classe média que possui interesses diretamente conflitante com os proprietários da terra urbana (pública ou privada). Esse conflito, portanto, diz respeito principalmente, à especulação imobiliária. De um lado, a classe média buscando espaços amplos e baratos, de outro, a terra urbana sendo objeto de especulação, aliados a uma ausência de políticas públicas habitacionais. (CARVALHO JÚNIOR, 2007)

A especulação fundiária não é de interesse da classe média, mas fundamental na dinâmica dos grileiros, já que na realidade do Distrito Federal a grande maioria das terras é pública. Como visto, a ausência de políticas públicas cria uma escassez de oferta e uma demanda que pressiona, possibilitando-Ihes ampliar a renda da terra. Esse conflito, geralmente, é solucionado mediante pressões das classes envolvidas no Estado.

Essas pressões sugerem implantação de infra-estrutura, desapropriação de terras e políticas habitacionais para a população diretamente envolvida. Esses agentes atuam no espaço urbano visando obter a maior rentabilidade no uso da terra. Dado que a terra urbana tem maior valor do que a terra rural, estes agentes se mobilizam objetivando a transformação de áreas rurais em urbanas. $O$ interesse inicial recai sobre a periferia agrícola, uma vez que os proprietários fundiários anseiam transformá-la em urbana, o que gerará, por conseqüência, valorização fundiária. 
Entretanto, essa passagem de área rural para área urbana não é simples, envolvendo diferenciais de demandas de terras e habitações, do aparecimento de novas camadas sociais, oriundas em parte de fluxos migratórios e que detém nível de renda que as torne capacitadas a participar do mercado de terras e habitações. Depende também das possibilidades de remuneração do capital investido em terras e operações imobiliárias e ainda da política que o Estado adota para permitir a reprodução do capital, como reforço do aparelho do Estado pelo aumento do número de funcionários e através da ideologia da casa própria". (CORRÊA, 1989; CARVALHO JÚNIOR, 2007).

Fatores como estrutura agrária, geomorfológica e dos futuros usos a serem dados à área também são importantes nesse processo. Áreas rurais, passíveis de especulações, tendem a ser mais visadas. Já áreas alagadiças, por exemplo, tendem a dificultar o processo de valorização fundiária almejado por estes agentes. Estes agentes também desencadeiam outros processos de valorização fundiária. Trata-se de uma espécie de reconfiguração de áreas, com tratamento diferenciado a bairros antes abandonados, ou seja, uma remodelação, ou maquiagem de uma determinada área, juntamente com campanhas publicitárias, visando dar um novo status a um determinado bairro, de modo que, o objetivo principal é a valorização fundiária. Neste ponto, cabe ressaltar que estes agentes, nesse momento, também agem como promotores imobiliários, pois ao mesmo tempo em que detém a posse da terra, também constróem, loteiam, fracionam. Percebe-se que não há interesse do proprietário fundiário transformar-se em promotor imobiliário, entretanto, no fracionamento é que o proprietário fundiário obtém uma valorização maximizada.

O fato de estarmos em uma sociedade capitalista, fomenta diferenciações de classes, de rendas e demais aspectos ligados ao cenário capitalista de acumulação. A habitação, também, se insere nesse cenário, uma vez que o acesso a ela é seletivo: nem todos têm renda suficiente para pagar ao menos um aluguel, quanto mais para adquirir um imóvel. Os que têm uma renda monetária que possibilite ao menos um financiamento, encontram enormes dificuldades para executá-lo e cumpri-lo os que nem isso tem, partem para a ilegalidade das ocupações irregulares. Essa modelação do espaço urbano, por parte dos grupos sociais, se dá num caráter de sobrevivência e também como uma forma de resistência. Sobrevivência muitas vezes por estarem excluídos das ações do Estado dentro da política habitacional e resistência pelo fato destes agentes almejarem mostrar o interesse pelo acesso à cidade, resistência essa muitas vezes acompanhadas de mobilizações em massa. (CORRÊA, 1989)

A localização das áreas ocupadas por estes agentes, inicialmente, podem parecer díspares, como no caso da micro-bacia do rio Samambaia, entretanto, há uma lógica, tendo em vista que sua ação se operacionaliza visando solucionar dois problemas críticos: o da habitação e o da acessibilidade ao local de trabalho.

Nas ocupações irregulares, mostra como se desenrola, geralmente, o processo de urbanização que resulta, de um lado, da ação dos próprios moradores que, pouco a pouco, durante um longo período de tempo, vão melhorando suas residências, implantando atividades econômicas diversas. De outro, advém da ação do Estado, que implanta alguma infra-estrutura urbana, seja a partir de pressões exercidas pelos moradores organizados em associações, seja a partir de interesses eleitoreiros. Esta 
urbanização, contudo, desencadeia uma valorização que acaba por expulsar alguns de seus moradores e atrair outros, como está ocorrendo na região. (CORRÊA 1989; CARVALHO JÚNIOR, 2007)

A complexidade das ações dos vários agentes que (re)produzem o espaço urbano, seus campos de atuação, convergências e conflitos foram aqui expostos e, dessa discussão se percebe, minimamente, práticas capitalistas de uso e ocupação do solo, visando sempre o lucro e a potencialização da renda a ser obtida através da terra urbana por parte dos três primeiros agentes expostos. Os grupos sociais, não detendo um capital substancial, ficam excluídos do processo, advindo daí o principal motivo de sua constituição buscando, assim, o atendimento de suas reivindicações para acesso à moradia, sejam elas para as camadas mais baixas ou médias.

A concepção capitalista que emana na realidade da ocupação territorial na micro-bacia do Rio Samambaia, não abarca o caráter social, trazendo consigo ocupações, que além de irregulares, trazem níveis vergonhosos de transgressões às leis fundiárias, sensação de impunidade, proliferação de máfias de "grilagem" de terras e o desrespeito total ao meio ambiente, esse último, o aspecto central deste estudo.

Outro aspecto interessante nessa discussão é que se percebeu também a carência de trabalhos teóricos sobre os conflitos ambientais urbanos no Distrito Federal, mesmo diante do crescente número de casos passíveis de estudo. Portanto impõe-se o desafio de fazer com que o presente estudo de caso seja mais que descrições das interações empíricas entre grupos sociais que produzem os territórios.

O cerne da constituição desse conflito sócio-ambiental está no modelo de gestão territorial adotado pelo Governo do Distrital, favorecendo os mecanismos mercadológicos produtor de desigualdades sócio-ambientais. Este colocou as populações de baixa renda na contingência de terem que acionar diversas estratégias de ação individual e coletiva para obter, o provimento dos serviços e equipamentos urbanos de consumo, a posse do solo, a habitação, a segurança ambiental etc. Os programas de assentamento das populações de baixa renda seguiram sem muito critério.

As pessoas eram colocadas em "novas cidades" sem a oferta dos serviços básicos. Sendo esse "programa" insuficiente para atender toda à demanda habitacional, criou-se a "lógica e a cultura" da invasão da terra pública. Esse fenômeno, associado à omissão Estatal, estimulou o advento de várias "bombas relógio" prontas para explodir ao primeiro sinal.

O modelo dos "condomínios" que foi adotado não só no Distrito Federal como também em diversos estados da federação, é uma expressão da ausência do Estado no provimento de políticas habitacionais, no não provimento eficaz de equipamentos urbanos de infra-estrutura e consumo coletivo e também às dificuldades de fiscalização.

Com efeito, o poder público, quando comparece, o faz premido pela ação reivindicativa e pelos conflitos protagonizados pela população organizada ou por processos de "regularização fundiária" onde já que não se sabe quem é o dono da terra, ela sempre será propriedade do Estado. A agência responsável por esse processo de venda e regularização de lote no DF é a TERRACAP, que os vende aos moradores ou 
abre licitações, cujos preços são objetos de contestação e litígio por parte dos moradores.

No modelo territorial dos "condomínios" em grande parte, a construção social do território urbano se fez pelo concurso de estratégias e ações empreendidas pela própria população local e por outros atores sociais. A ação estruturalmente enviesada do Estado e os mecanismos mercadológicos agravam o quadro de desigualdade socioambiental com que se defronta a população estudada. Nesse quadro, a população local se mantém ao longo do tempo em permanente estado de alerta e mobilização, para obter dos poderes públicos (e/ou para constituir por si mesma) o provimento dos serviços de infra-estrutura urbana. Acompanhando-se o monitoramento temporal do uso e ocupação territorial foi possível perceber o crescimento populacional na micro-bacia do Rio Samambaia, provocado, em parte, pelo crescimento vegetativo, e, em parte, pela chegada de novos moradores - atraídos pelas melhorias urbanas alcançadas e pelos custos relativamente mais baixos de moradia - acarreta a necessidade de novas mobilizações e conflitos. Nesse sentido, os conflitos ambientais são elementos constitutivos do próprio padrão de construção social do território urbano habitado por população da micro-bacia.

Matrizes do Conflito Sócio-ambiental

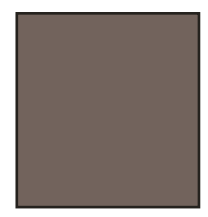

Matriz Ambiental:A Questão da Floresta Ripária

Faixa de 30 metros protegidas pelo Código Florestal Brasileiro, onde na realidade da bacia do Córrego Samambaia não se permite a presença de edificações em sua margem. Essas áreas são de uso proibido e prioritárias para conservação. A erradicação de edificações presentes nessas áreas é quesito fundamental para o licenciamento ambiental do bairro, e vem sendo usado como argumento para disputas e desgastes políticos entre GDF e União. As edificações nela existentes, não podem receber as benfeitorias de infra-estrutura básica como água, luz e esgoto. São áreas habitadas principalmente por pessoas de baixa renda.

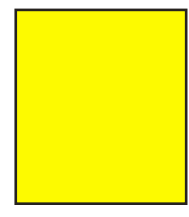

Matriz Fundiária: A Questão da Posse da Terra

A matriz fundiária é sem dúvida quesito fundamental, já que ainda é confusa a questão da posse da terra na Bacia. União e GDF ainda não apresentaram uma poligonal clara, os limites de cada posse. Os moradores iniciais receberam as chácaras na forma de arrendamento. Entretanto essas foram vendidas, revendidas e fracionadas pelas décadas, aumentando ainda mais a dificuldade de esclarecer a posse da terra. A faixa de 30 metros protegidas pelo Código Florestal Brasileiro, foi o estopim do conflito. Essas áreas são de uso proibido e prioritárias para conservação. Para as áreas fora das APP o GDF inicia um modelo de regularização fundiária questionável. 


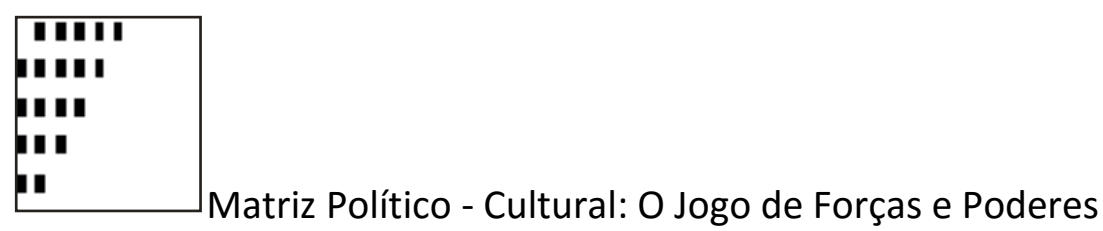

Sem dúvida um tema delicado de ser tratado, mas a questão desse conflito tem servido como pretexto para desgastes entre a União e o GDF, no momento de partidos políticos opostos. A Justiça determina a erradicação de edificações, a União cobra e o GDF, que executa, diz que as erradicações são desgastantes e dificeis de serem feitas. Periodicamente aparecem políticos distritais em defesa da população da bacia. Eles aparecem no dia das operações de erradicação, e causam tumulto, dificultando o trabalho. Alguns usam isso para se promoverem na região. A matriz cultural se refere ao modelo de ocupação territorial pelo qual passou o Distrito Federal nas últimas décadas. A fusão de ausência de políticas habitacionais coerentes, aliadas a uma demanda habitacional, fomentou a especulação imobiliária e a cultura da invasão da terra pública.

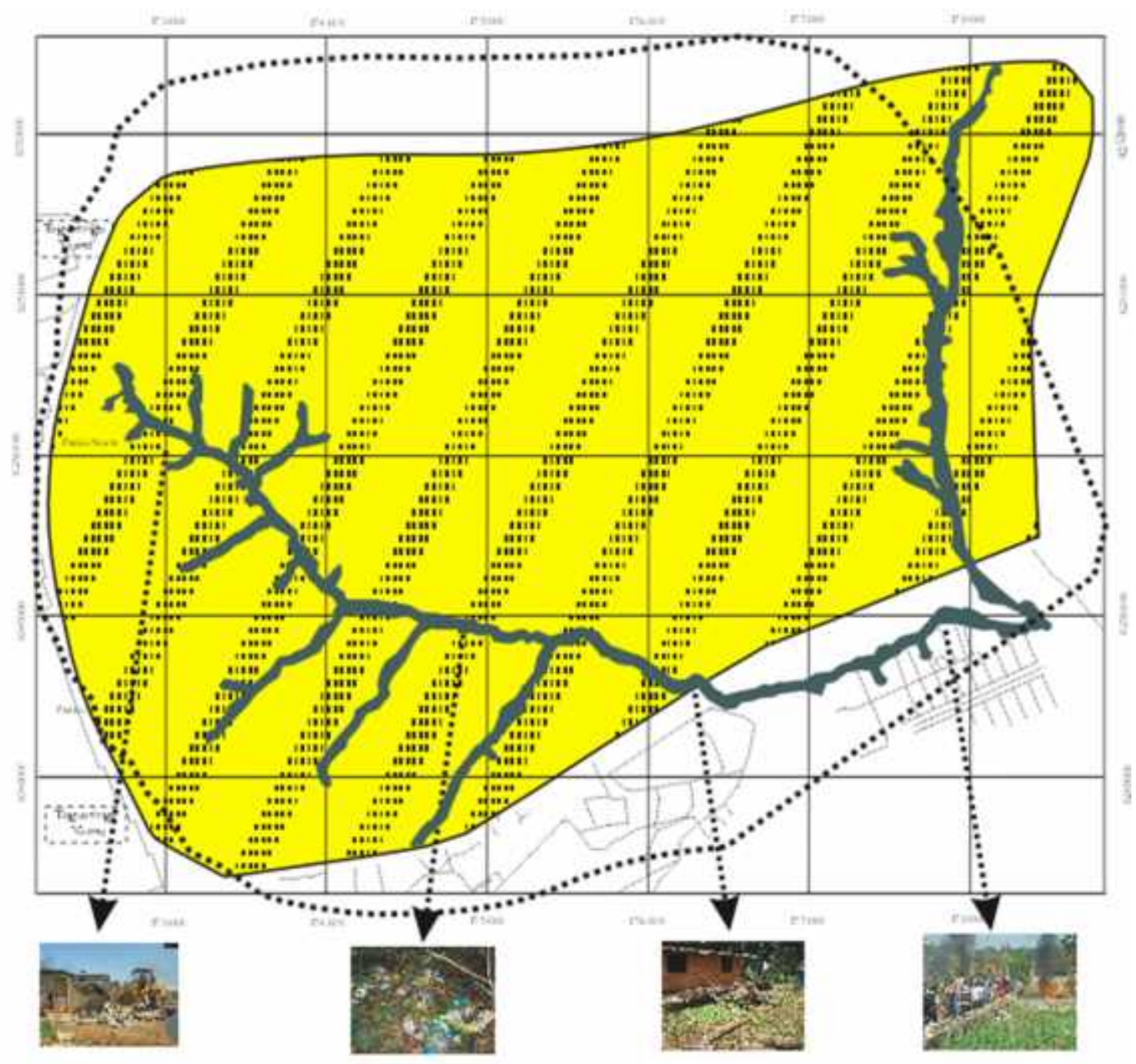

\section{Conclusões e Recomendações}


Com o presente trabalho percebeu-se que ocupações irregulares são fontes geradoras de passivos ambientais em áreas urbanas que contribuem para a descaracterização do meio natural das grandes cidades.

A dificuldade de acesso à terra por meios legais estimula parte da sociedade a buscar outros mecanismos, por vezes ilícitos, para satisfazer sua demanda habitacional. O déficit, ocasionado pela incapacidade de gestão por parte Estatal, somado a processos migratórios e à especulação imobiliária fomenta o comprometimento de áreas de preservação permanente e a eclosão de conflitos socioambientais na micro-bacia do Rio Samambaia.

É essa ausência estatal, que estimula a auto-organização das populações nos loteamentos irregulares em massa ou "condomínios" são vistos como um modelo de solução paradoxalmente legítima e adequada para resolver a demanda habitacional brasiliense, e ainda assim auferir enormes ganhos políticos com esses erros para, a seguir, gastar fortunas do dinheiro público para "consertar" os danos ambientais, sociais, paisagísticos, patrimoniais, de infra-estrutura, gerados.

As áreas preferidas para o parcelamento irregular são as encontradas em Áreas Rurais Remanescentes, já que são áreas ainda não consolidadas em urbanas e passíveis de fracionamento. O maior problema encontrado no parcelamento destas áreas é o fato de que, em sua grande maioria, estão localizadas em regiões cujo meio natural tem características mais sensíveis e que ainda desenvolvem atividades de sua vocação original.

O jogo de interesses dos atores envolvidos foi heterogêneo no local. Acreditase que a ação desses atores foi fundamental para entender o processo de constituição e evolução do conflito. Outro quesito fundamental é visualizar que os principais agentes não foram eleitos no início do processo, mas constituíram-se e estabeleceramse paulatinamente durante todo o processo.

As Áreas de Proteção Permanente (APP) da micro-bacia do rio Samambaia: matas galerias, nascentes, rios que cortam o local, áreas com declividade acima de $30 \%$, necessitam, em grande parte, serem protegidas e recuperadas como quesito fundamental para o processo de licenciamento do setor habitacional contido na microbacia em estudo.

A mediação e resolução dos conflitos ocorrentes na micro-bacia do Rio Samambaia, passa pelo reconhecimento das interconexões ou inter-relações, entre as dimensões econômicas, sociais, ambientais, culturais e políticas existentes. Para tanto, torna-se fundamental que exista uma postura de relações horizontais, as quais devem promover, entre outras coisas, a participação coletiva no processo de mediação.

Os conflitos na micro-bacia do Rio Samambaia passaram do estágio inicial de potenciais ou latentes, onde os fatores estruturais do litígio se condicionavam, mas sem a contenda plenamente estabelecida, para conflitos manifestos, onde os atores no confronto tomam medidas de defesa de seus interesses, as vezes em detrimento da solução e restringindo a busca de diálogo e mediação. É curioso perceber que foi justamente o início do processo de licenciamento ambiental (um instrumento legal) do bairro que deflagrou essa contenda, mediante a necessidade de erradicação de edificações em áreas de preservação permanente. 
O maior desafio para gestão desse conflito é o de como os atores criarem um mecanismo de mediação que estabeleça o modelo recomendado por Nascimento (2001), de "ganha-ganha", onde os anseios de todos os atores sejam pelo menos parcialmente atendidos, e nenhum deles se sinta prejudicado ou preterido no processo de busca do consenso. Como foi percebido que algumas partes buscam apenas a defesa de seus interesses, a solução está a médio ou longo prazo.

No caso estudado, a melhor forma de resolução do conflito seria a sua gestão e dentre os tipos de resolução apresentados por Little (2001) o do diálogo/cooperação seria o mais adequado. Para situações de conflito sobre desenvolvimento sustentável os grupos em litígio necessitam de diálogo para chegarem a um consenso, porém necessitando de um mediador, que no caso da Bacia em estudo, é o Ministério Público mediante o Termo de Ajustamento de Conduta (TAC).

Nesse conflito envolvem-se atores de diversas vertentes, com relações assimétricas de poder e onde o relacionamento entre o meio ambiente e a sociedade está em jogo. Nesse manejo das forças buscando-se a mediação desse conflito fatores importantes no processo são: a) melhorar os processos de tomadas de decisões; b) promover espaços que permitam acordos eqüitativos; c) reafirmar o poder e a legitimidade dos atores envolvidos; d) oferecer um processo de mediação transparente; e) comprometer os atores com os resultados acordados e f) deflagrar um processo de aprendizagem sobre a validade do diálogo como forma de enfrentar e prevenir conflitos.

\section{Referências Bibliográficas}

ASCERALD, HENRI. Conflitos ambientais no Brasil. Rio de Janeiro: Relume Dumará: Fundação Heinrich Böll, 2004.

CARNEIRO, EDER JURANDIR \& BARROS, MATHEUS ALVES DE Conflitos Ambientais e Construção de um Território Urbano: 0 Caso do B airro São Dimas (São J oão del-Rei MG) III Encontro da Associação Nacional de Pós Graduação e Pesquisa em Ambiente e Sociedade. 23 a 26 de maio de 2006. Centro de Convenções Israel PinheiroBrasília - Distrito Federal - Brasil

CARVALHO JUNIOR, WILSON MARTINS DE Os impactos ambientais decorrentes da ocupação urbana: o caso da Colônia Agrícola Vicente Pires - Brasília/DF, 203p., 297 mm, (UnB - GEA, Mestre, Gestão Ambiental e Territorial, 2007). Dissertação de Mestrado Universidade de Brasília. Departamento de Geografia.

COELHO, M.C.N. Impactos Ambientais em Áreas Urbanas - Teorias, conceitos e metodologia de Pesquisa. In: GUERRA, A.J.T \& CUNHA, S. B.(Prgs) Impactos Ambientais Urbanos no Brasil. 3ํㅡㄹ. Rio de Janeiro: Bertrand, Brasil, 2005.

CORRÊA, Roberto Lobato. O espaço urbano. São Paulo: Ática, 1989. 94p.

CORREAA, ROBERTO LOBATO; ROSENTHAL, ZENY. Paisagem, tempo e cultura. Rio de Janeiro: Editora UERJ, 1998.

FAUSTINO, J. Planificación y Gestión de Manejo de Cuencas. Turrialba: CATIE, 1996. 90p. 
HAESBAERT, ROGÉRIO. Região, diversidade territorial e globalização. GEOgraphia - Ano. 1 - No 1 -1999. 25p.

LEFF, HENRIQUE. Saber Ambiental: Sustentabilidade, racionalidade, complexidade e poder. Trad. Lúcia M. Endlich Orth. Petrópolis: Vozes, 2001.

LITTLE, PAUL. Os conflitos socioambientais: um campo de estudo e da ação política. In: Bursztyn, Marcel. A Difícil Sustentabilidade. Rio de Janeiro: Garamond, 2001.

MACIEL, SÔNIA MARIA BAENA. O Processo de Ocupação da Colônia Agrícola Vicente Pires: ação antrópica e impactos ambientais. Dissertação de Mestrado - Programa de PósGraduação Stricto Sensu em Planejamento e Gestão Ambiental - Universidade Católica de Brasília. Brasília, 2001, 140 f il.

MONTE-MOR, R.L.M. Urbanização Extensiva e Lógicas de Povoamento: um olhar ambiental. In: SANTOS, M; SOUZA, M.A. de \& SILVEIRA, M.L. (Orgs.) Território, Globalização e Fragmentação. São Paulo: Hucitec, 1994

NASCIMENTO, ELIMAR. Os conflitos na Sociedade Moderna: uma Introdução Conceitual. In: Bursztyn, Marcel. A Difícil Sustentabilidade. Rio de Janeiro: Garamond, 2001.

RAFFESTIN, Claude. Por uma geografia do poder. São Paulo, Ática, 1993.

SCHIER, RAUL ALFREDO. Trajetórias do conceito de paisagem na geografia. R. RA'E GA, Curitiba, n. 7, p. 79-85, 2003. Editora UFPR.

SANTOS, M. A natureza do espaço. Técnica e tempo. Razão e emoção. São Paulo: Hucitec, 1997.

SANTOS, Milton. O Pensamento, Encontro Internacional Espécie, Espaço, Estado - ou Desafio do Ordenamento Territorial. Disponível em: <www.alfa.br/revista/pdf/7tur.pdf>. Acesso em: 20 maio 2005.

SOUZA, E. R. de; FERNANDES, M. R. Sub-bacias hidrográficas: unidades básicas para o planejamento e a gestão sustentáveis das atividades rurais. Informe Agropecuário, Belo Horizonte, v.21, n.207, p.15-20, nov./dez. 2000.

TROLL, C. El paisage geográfico y su investigación. MENDONZA, J. G. ; JIMENEZ, J. M. y CONTERO, N. (Org.) El pensamiento geográfico. Estudio interpretativo y antologia de textos (De Humboldt a las tendências atuales). Madrid: Alianza Editorial, 1982.

UNESCO. Vegetação no Distrito Federal - tempo e espaço. Brasília, 2000, 74p. 